
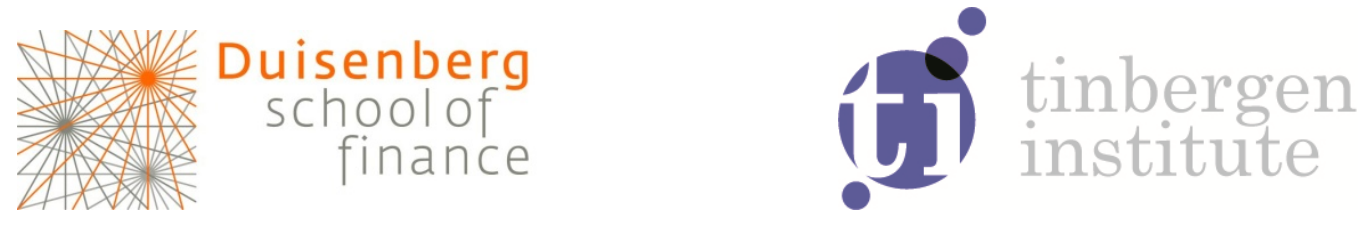

Duisenberg school of finance - Tinbergen Institute Discussion Paper

\title{
TI 13-186/IV/DSF68
}

\section{Short-Selling, Leverage and Systemic Risk}

\author{
Amelia Pais ${ }^{7}$ \\ Philip A. Stork ${ }^{2}$
}

1 Massey University, College of Business, School of Economics and Finance, Auckland, New Zealand;

2 Faculty of Economics and Business Administration, VU University Amsterdam, Tinbergen Institute, and Duisenberg School of Finance. 
Tinbergen Institute is the graduate school and research institute in economics of Erasmus University Rotterdam, the University of Amsterdam and VU University Amsterdam.

More TI discussion papers can be downloaded at http://www.tinbergen.nl

Tinbergen Institute has two locations:

Tinbergen Institute Amsterdam

Gustav Mahlerplein 117

1082 MS Amsterdam

The Netherlands

Tel.: +31(0)205251600

Tinbergen Institute Rotterdam

Burg. Oudlaan 50

3062 PA Rotterdam

The Netherlands

Tel.: +31(0)10 4088900

Fax: +31(0)104089031

Duisenberg school of finance is a collaboration of the Dutch financial sector and universities, with the ambition to support innovative research and offer top quality academic education in core areas of finance.

DSF research papers can be downloaded at: http://www.dsf.nl/

Duisenberg school of finance

Gustav Mahlerplein 117

1082 MS Amsterdam

The Netherlands

Tel.: +31(0)20 5258579 


\title{
Short-Selling, Leverage and Systemic Risk
}

\author{
Amelia Pais and Philip A. Stork ${ }^{*}$
}

This version: 5 November 2013

\begin{abstract}
During the Global Financial Crisis, regulators imposed short-selling bans to protect financial institutions. The rationale behind the bans was that "bear raids", driven by short-sellers, would increase the individual and systemic risk of financial institutions, especially for institutions with high leverage. This study uses Extreme Value Theory to estimate the effect of short-selling on financial institutions' individual and systemic risks in France, Italy and Spain; it also analyses the relationship between financial institutions' leverage and short-selling. The results show that short-sellers appear to specifically target institutions with lower capital levels. Furthermore, institutions' risk-levels and changes in short-selling positions tend to move in tandem.
\end{abstract}

Keywords: bear raids, short-selling bans, financial institutions' risk, systemic risk, leverage capital requirements, Extreme Value Theory.

JEL classification: C14; G01; G15; G21.

${ }^{*}$ Pais is Senior Lecturer in Finance at Massey University, College of Business, School of Economics and Finance, Private Bag 102 904, North Shore Mail Centre, Auckland, New Zealand. Tel.: +64 9414 9226; fax: +64 9441 8177. Stork is Professor of Financial Markets and Instruments at VU University Amsterdam, Faculty of Economics and Business Administration, School of Finance and Risk Management, Room 3A-16, De Boelelaan 1105, 1081 HV Amsterdam, The Netherlands. Tel.: + 312059 83651. Stork is also a Research Fellow at Duisenberg school of finance. E-mail addresses: a.pais@massey.ac.nz,p.a.stork@vu.nl.We thank Markit Securities Finance for providing us with their proprietary data. 


\section{Introduction}

In the wake of the Global Financial Crisis, regulators across the world have concentrated on mitigating systemic risks. Systemic risk happens when one institution's failure spreads to related agents or markets through financial transactions or financial linkages. Such crises impose large costs on the taxpayer because regulators are forced to rescue the failed institutions. Short-selling bans were used by regulators during the Global Financial Crisis to prevent market panics. These bans were imposed at times in which falling stock markets and great distress in financial institutions were severely undermining investors' confidence and worrying regulators and politicians. The bans aimed at stopping "bear raids". In a "bear raid", many traders short sell large amounts of a firm's stock, forcing the price down. For the price manipulation to be profitable, the short-sellers need to generate panic and a lack of confidence amongst investors and other firm counterparties. As a result, the initial drop in price impacts the fundamentals of the firm, which generates a feedback effect that further increases pressure on the share price.

The first ban was imposed on $19^{\text {th }}$ September 2008 in the US and the UK to respond to the panic generated by the collapse of the sub-prime mortgage market. Most countries followed these actions and introduced bans shortly afterwards (Gruenewald, et al., 2010). The European sovereign debt crisis, which affected European banks' funding costs (especially short-term interbank costs) in various ways (BIS 2011), persuaded a group of regulators (Belgium, France, Italy and Spain) to coordinate another ban on August $11^{\text {th }} 2011$. In both cases, regulators defended the need for short selling restrictions by referring to the herding behaviour of short sellers, driven by their negative view of financial institutions. Such herding could potentially also affect fundamentally sound institutions by putting downward pressure on share prices.

The stability of the financial industry rests on public confidence, and the industry is vulnerable to "panic runs". Because stock prices are forward looking, falling share prices affect the confidence of current and future creditors and investors, thus further supporting a lower valuation because institutions with low capital run a greater risk of default. Decreases in these institutions' stock prices reduce their ability to raise more capital and force the inefficient liquidation of assets, which further weakens stock prices. Acharya et al. (2012) highlight the contribution of excessive leverage in propagating a crisis. When aggregate capital is low, there are no healthy financial 
firms able to buy or cover the functions of other insolvent institutions. Firms with very low capital levels will generate the highest systemic risk when the financial sector as a whole is low in capital because no other firm in the system can assume their liabilities. In this sense, financial institutions with the lowest capital buffers would be the most vulnerable to the type of price manipulation some attribute to short sellers, and abusive short-selling could potentially increase the volatility and contagion risk of financial institutions.

Recent research on the short sale restrictions imposed during the financial crisis has looked at the consequences of the ban on stock liquidity, price discovery, and returns ${ }^{1}$. Most research finds that bans have a negative effect on stock markets, but that is not surprising if one thinks of the bans as similar to a suspension of convertibility to prevent a bank run ${ }^{2}$. The suspension breaks the terms of the deposit contract, but it gives banks space to restore liquidity and regain the depositor's confidence. This study adds to this body of research by exploring the bans from a perspective of financial stability. The focus is on the factors that drove market regulators to impose the short-selling bans and whether the bans were preventing a larger systemic crisis. If the bans on short-selling have some temporary negative impact on market liquidity or efficiency, the impact is likely to be less expensive than the cost of rescuing one or more financial institutions.

This study makes two major contributions to the literature. First, it tries to determine whether short-sellers were targeting the financial institutions with the highest leverage. Second, it analyses whether short-selling increases institutions' individual and systemic risks ${ }^{3}$. The results show that changes in both univariate and contagion risks are positively related with changes in short-selling positions. The results also show that low capital adequacy ratios for banks (or higher leverage for insurance companies) tend to correspond with larger short positions.

\footnotetext{
${ }^{1}$ See next section for a literature review.

${ }^{2}$ In a bank run, depositors who have lost confidence in a bank rush to withdraw their funds, prompting the bank to inefficiently liquidate assets and precipitating the bank's failure: Diamond and Dybvig (1983) show how temporary suspension of the ability to convert deposits into cash may short-circuit a bank run.

${ }^{3}$ This paper extends previous research by Pais and Stork (2012).
} 
The paper is organised as follows: the next section reviews the literature and the context of the bans, section 3 estimates the relationship between short selling and financial institutions' risks, section 4 analyses the relationship between short-selling and institutions' capital, and section 5 concludes.

\section{Short-Selling and Price Manipulation.}

Just before the GFC, short-selling was generally permitted around the world ${ }^{4}$. Certain activities around short selling, such as disseminating false rumours to depress the price of shorted stocks or the use of trading strategies aimed at "pummelling" stock prices and undermining the confidence of long-position holders, were already illegal $1^{5}$. This type of market abuse, aimed at destabilising financial institutions' stocks with the intention to profit from the downward spiral of prices is the primary reason for the short-selling bans of the GFC.

The financial and economic press is full of recounts of cases in which CEOs complain about the damaging effect of short selling (which some also regard as immoral because short-sellers benefit from somebody else's losses). Prominent voices in the finance world, such as George Soros, have expressed negative views on their activities. Others, such as Misra et al. (2012), provide detailed evidence of a bear raid, in their case against Citigroup's stock in November 2007. Some members of the financial press have also blamed aggressive short-sellers for precipitating the fall of Bear Stearns and Lehman Brothers.

The recent literature analyses the likelihood of feedback effects from stock prices on fundamentals. For example, Subrahmanyam and Titman (2001) argue that a firm's stock price affects how its counterparties (e.g., creditors, investors, suppliers, clients) view the firm. This view will influence their decisions regarding the firm, which in turn will have an effect on the firm's cash-flow and fundamental valuation. Ozdenoren and Yuan (2008) go one step further and

\footnotetext{
${ }^{4}$ With some exceptions regarding naked short selling (selling short without ever securing the stock) and some versions of the "uptick rule" (short sales are only permitted on an upward movement of the stock price, i.e., at a price that is higher than the preceding price). The "uptick rule" was eliminated in 2007 in the US.

${ }^{5}$ For an explanation of these trading strategies see Duffy (2008).
} 
model the possible coordination of aggregate investors in the presence of feedback effects. Investors realise it is best to buy when everybody is buying, or to sell when everybody is selling.

A natural extension to feedback effects is to look at price manipulation and to examine the possible use of short-selling to de-stabilise prices in such a way that it benefits trading strategies that are initiated by short-sellers.

Of particular relevance to this study are the works of Brunnermeier and Oehmke (2013) and Liu (2010). Brunnermeier and Oehmke (2013) develop a model in which financial institutions are susceptible to "predatory" short-selling and provide a theoretical argument to justify the shortselling bans. Financial institutions are subject to capital requirements to limit their leverage. Through their aggressive trading, short sellers may cause banks to violate these requirements (especially when financial institutions are near their maximum permitted level of leverage) and force them to sell long-term assets at discounted values to improve their capital positions. These sales further depress the stock values and render the short-seller positions profitable. This effect is more relevant during periods in which financial institutions have weak balance-sheets because short-sellers can trigger the total unwinding of financial institutions' long-term investments merely by short-selling their stock. In the absence of short-selling, the financial institutions would have met their leverage constraints and would not have been forced into inefficient liquidation. Coordination amongst short-sellers who can see each other's positions is decisive in bringing down a financial institution. Recent regulatory changes to promote market transparency thus facilitate the short-traders' strategies.

Liu (2010) builds a model in which short-selling can also cause the failure of a sound bank, especially if the bank has weak fundamentals and severe maturity mismatches. The mechanism in this case is imperfect information about fundamentals combined with market illiquidity. If the market is illiquid, short-sellers can influence and dampen the stock price; the asymmetric information forces creditors to use the banks' stock to learn about fundamentals; and the uncertainty and low stock price increase the downside risk of creditors, leading to a reduction in debt value, which in turn may cause creditors to run and eventually lead to the bank's failure. In this setting, short-selling can also generate systemic risk when the fall of one or more institutions causes a negative externality (decrease in confidence) to other banks by reducing the 
fundamentals of other banks. In an extreme case, even healthy banks will become weaker. This would trigger a new round of short-selling that can cause a cycle in which many financial institutions collapse.

Other research looks at short selling strategies non-specific to financial institutions. For instance, Brunnermeier and Pedersen (2005) model "predatory trading" practices as trading strategies for which the aim is to withdraw liquidity from the market when it is most needed, causing prices to overshoot and even forcing large investors to liquidate their positions. Predatory traders would sell when large investors need to sell and thus increase the illiquidity of the market, leading prices to deviate from their fundamentals. Such traders anticipate the order flow. They take short positions and trade in the same direction as the troubled investor to benefit from the ensuing price swings. The profits, and therefore, the incentives to engage in predatory trading, are larger during a financial crisis because the price swings and the crisis will be further amplified by "panic" selling by vulnerable investors. Moreover, the continuous drop in stock prices will affect the wealth of other investors who will have to keep selling, thus depressing prices more.

Goldstein and Guembel (2008) develop a model in which feedback effects between the financial markets and the real value of firms may motivate firms to bypass valuable investment opportunities and cause an inefficient allocation of resources. Traders who can anticipate this have an incentive to short sell the stock of a firm and drive the price down with additional sell orders. The drop in stock price pushes the firm to cancel the valuable investment project and further reduces the value of the firm. This will allow the trader to generate profits from the short position.

Shkilko et al. (2012) argue that short sellers try to influence intraday returns to cause negative price overreactions and extreme return reversals (indicative of predatory trading) in intraday trading. They also report that aggressive short-selling makes markets more illiquid. Bocher et al. (2008) argue that hedge funds have an incentive to manipulate "end of the day returns" and "year-end" returns to influence compensation. They find significant increases in short selling volume at the end of these periods and lower returns for stocks in which hedge funds hold large short positions. Henry and Koski (2010) find evidence of price manipulation by short-sellers 
around the issue date of "seasoned equity offers" (SEO): short sellers will try to lower the offer price to profit by covering their short position at a lower price. Khanna and Mathews (2012) model bear raids in which the firm under attack has large blockholders who will try to battle the price manipulation driven by short-sellers. Under certain circumstances it would be too costly for the blockholders to continue defending the stock, and regulatory intervention would be required to restore prices to fundamental values.

This study is also related to recent literature that examines the short-selling bans of $2008^{6}$, particularly the effects of those restrictions on market liquidity and efficiency. The majority of this literature concludes that short-selling bans have been damaging to stock markets. Of special concern was the effect of the ban on liquidity when market participants were already suffering illiquidity from other markets as a consequence of the GFC. Beber and Pagano (2013) conclude that the bans reduced liquidity and price efficiency across 30 countries; furthermore, financial institutions' stock prices continue the downward price spirals after the ban. Boehmer et al. (2013) find that the ban triggered a significant drop in shorting activity in the NYSE and NASDAQ markets and that liquidity was negatively affected. Autore et al. (2011) report a similar illiquidity shock as a consequence of the ban and a valuation reversal for banned stocks as predicted by Miller (1977). Marsh and Payne (2012) describe a drop in market liquidity and increase in trading costs for the UK market during the ban period. Battalio et al. (2011) investigate whether the decline of US financial stock prices was amplified by short-sellers. They find no relationship between short-selling activity and the drop in prices.

\subsection{Testable Hypotheses}

Given the previous theoretical and empirical literature, this study tests two hypotheses regarding these bans:

First, short selling increases financial institutions' individual and systemic risk; consequently, at times of market disruption a ban on short selling these institutions' stocks may prevent greater systemic events from taking place.

\footnotetext{
${ }^{6}$ The first bans were imposed in Australia, Canada, Germany, Switzerland, UK and the US.
} 
Second, short sellers target institutions with lower capital buffers because their trading strategy is likely to be more successful at affecting investors' confidence and generating panic selling (and a downward price spiral) for such institutions.

\section{The relationship Between Short-Selling and Financial Institutions Risk}

\subsection{Methodology}

Individual or univariate (VaR) risk is the likelihood of large negative returns in a stock, and systemic risk or multivariate (VaR) risk is the likelihood that a large negative return in a bank's stock coincides with a large drop in another bank's stock; both are estimated using Extreme Value Theory (EVT). EVT can be used to analyse extremely rare (low probability) events and how they spread across financial institutions and markets. The prevention of such extreme events is what regulators are aiming for when imposing short selling bans because of their significant effects on the financial system and the real economy. The non-parametric EVT-metrics are based on Hartmann et al. (2004) and Straetmans et al. (2008). Please see Pais and Stork (2011) and Appendix A in this study for a detailed description of the EVT methodological framework and for recent applications.

\subsection{Data Description}

Daily total return indices for financial institutions in France, Italy, and Spain were obtained from Datastream $^{7}$. The series start on 17 April 2001 because of the unavailability of data before this date. The end date of all series is 19 March 2012. All series are denoted in euro. Those series for which no complete dataset was available were removed. These included the institutions that had not been listed by 17 April 2001, were delisted before 12 August 2011 (ban date), and those without short selling data. The data sample contains a total of 45 institutions: 9 in France, 26 in Italy and 10 in Spain.

\footnotetext{
${ }^{7}$ Belgium also banned short selling of financial institutions' stocks on the same date, but was left out of the dataset because of the small size of the Belgium market.
} 
The short-selling data were obtained from Markit Securities Finance. This company captures "stock loan trading information from over 100 participants and approximately $85 \%$ of the OTC securities lending market" (Data Explorers, 2011). The data contain information on short positions down to the individual security level. We use their own metric, 'utilisation' (or utilisation rate), which indicates the value of a stock being utilised for securities lending against the total value of inventory available for lending. In this study, we refer to this metric as the 'relative short position'. The metric is calculated as follows:

$$
\frac{\text { Beneficial Owner Value on Loan }}{\text { Beneficial Owner Inventory Value }} \times 100=\text { Relative Short Position. }
$$

The above calculation results in a percentage that ranges between $0 \%$ and $100 \%$. We include only the wholesale lending side in the calculation. We use only Record Type 1 (e.g., all dividends) and limit the data to utilisation rates from the local markets. Thus, if the shares of a Spanish institution are dually listed on the Madrid stock exchange and on a foreign stock exchange, only the utilisation rates from the local market (Madrid, in this case) ${ }^{8}$ are used.

For every institution in the sample, during five monthly periods, we extract utilisation rates from the Markit Securities Finance database. We select the month of June from 2007 to 2011. We choose this month because it is less likely to exhibit various calendar effects, such as January (January-effect), May (“Sell in May and go away"-effect), July and August (summer months with low liquidity, and the ban month of 2011) and December (end-of-year effects). The shortselling data starts in 2007 because the older data are not very reliable because there are fewer observations and many of the market participants elected not to disclose their holdings. For every day in each of the five June periods and for every financial institution, our proprietary software programme downloads the relevant utilisation rate from a list of approximately $10,000-15,000$ short positions.

\footnotetext{
${ }^{8}$ We did check the relevance of including UK share market utilization rates but found it to be low and did not change our results.
} 
These daily utilisation rates per financial institution are then averaged. Averaging the short positions makes them more stable and, as a result, less dependent on day-to-day market fluctuations, which are not very informative. Averaging also removes the effects of short selling positions held for very short periods of time by market-makers providing liquidity to the markets. The use of average utilisation rates matches well our risk metrics, which also correspond to longer periods rather than specific days. The risk and utilisation metrics thus reflect period-averages rather than daily observations. As an illustration, see below the daily utilisation rates of two financial institutions for the five calendar months analysed.

$<<<$ PLACE FIGURE 1 AROUND HERE $>>>>$

Figure 1 provides insight into the behaviour of short-sellers. It is worth noting the large differences in short selling activity across financial institutions, both over time and across borders; for example, short position levels can go through fairly stable periods (see June 2008, where Banco Popular's short position levels stayed at approximately $80 \%$ ) as well as very volatile periods (see June 2010 for Generali, where the levels dropped from over $62 \%$ to $16.21 \%)$.

\subsection{Empirical Results}

Table 1 presents summary statistics of all return series. Returns are calculated as daily percentage differences of the Datastream total return indices.

\section{$\ll<<$ PLACE TABLE 1 AROUND HERE $>>>>$}

Table 1 shows that the average return over the full sample period is slightly positive for most financial institutions (average return equal to 1.99 per cent per year). A closer look at the returns in Table 1 also reveals that some institutions have performed much better than others. Several institutions generated a strongly positive total return over the sample period, such as Mapfre $(+14.46$ per cent) and Grupo Catalana Occidente (+18.38 percent). However, others performed dismally, with average returns strongly negative, such as Banco Popolare Etruria (-8.83 per cent) and Unipol (-9.62 per cent). Furthermore, Table 1 shows that minimum one-day returns range 
from a subdued -7.17 per cent for Credito Artigiano to a massive -37.91 per cent for April. Maximum returns start at +10.32 per cent for Banca Ifis and range up to +50.13 per cent for Milano Assicurazioni. Lastly, the bottom row shows that, on average, the skews are approximately zero but that kurtosis is quite high. Hence, although the returns are fairly symmetrical, they are fat-tailed.

\section{$<<<$ PLACE TABLE 2 AROUND HERE $\gg>>>$}

Table 2 reports the individual risks of the financial institutions on the sample. These risks have increased over time, as the sub-prime crisis came to full intensity in the fall of 2008. Average 99.90\% VaR levels increased from 8.93 per cent in June 2007 to 11.42 per cent in June 2009, as documented in the bottom row, which is a substantial relative increase of 28 per cent $(=(11.42-$ 8.93) / 8.93). Although the VaRs subside somewhat in June 2010 and June 2011, they remain at an elevated level compared with the first half of the sample. Table 2 also shows that the VaR levels are quite different across individual financial institutions. As an illustration, the Italian bank Credito Artigiano had a VaR of only 4.21 per cent in June 2007. On the other hand, Scor's VaR equalled 21.87 per cent in June 2007, much higher than Credito Artigiano's VaR and also clearly exceeding the average financial institution's $\mathrm{VaR}$, which was 8.78 per cent in that calendar month.

Table 3 focuses on multivariate VaR-levels, which measure contagion or systemic risk amongst institutions and how contagion varies over time.

\section{$<<<<$ PLACE TABLE 3 AROUND HERE $>>>>$}

Table 3 documents that, on average, systemic risks have increased strongly over the sample period. From the bottom row, it is evident that systemic risks increased from approximately 16 per cent on average for June 2007 to an average of approximately 25 per cent for June 2011. Between June 2008 and June 2009, the average systemic risk increased by 48 per cent, calculated as (24.36-16.43)/16.43, which is considerably more than the relative increase of 28 per cent witnessed in individual VaR-levels over the same period (this is consistent with other research that shows that contagion risk rose substantially during the Credit Crisis; see, for example, Pais and Stork (2011)). There are nonetheless some exceptions to the rises in systemic risk amongst the French financial institutions. Axa, BNP Paribas, April, Euler, Scor and Société Générale 
show falling VaR-levels between June 2007 and June 2011, albeit only minimally in some cases. The strongest increases in our multivariate risk measure are exhibited by the Spanish institutions, where, for instance, BBV Argentaria's VaR more than doubles, changing from 17.22 per cent to 38.68 per cent, and where Mapfre’s VaR spikes from 14.17 per cent to 36.32 per cent.

Next, we test our first hypothesis: is there a relationship between short positions and risk levels? Figure 2 provides a first insight into this question.

\section{$<<<$ PLACE FIGURE 2 AROUND HERE $>>>>$}

Figure 2 depicts, for two arbitrarily chosen institutions, how VaR-levels and short positions are linked over time. The left panel of Figure 2 suggests the presence of a strongly positive relationship: as short positions fall over time, so does the VaR. However, the opposite seems to happen with Société Générale, where falling shorts coincide with increasing VaR-levels. Our findings for the remaining 43 financial institutions in the sample indicate that both positive and negative relationships occur, and no consistent pattern emerges ${ }^{9}$.

Next, to investigate in greater detail whether univariate risk levels can be linked to short positions, we now focus on results per country instead of per individual financial institution.

\section{$<<<$ PLACE FIGURES 3.A. and 3.B. AROUND HERE $>>>>$}

Figure 3.A. depicts the relationship between short positions and VaR-levels for each country. Again, similar to the results in Figure 2, we obtain conflicting results: positive for France, nonexistent for Italy and negative for Spain.

To further analyse this matter, we also calculate the relationship between the first differences of both VaR-levels and short positions over time. Figure 3.B. shows that the link tends to be positive but rather unstable. For the changes from 2007 to 2008 and 2010 to 2011, a positive relationship is found, with an $\mathrm{R}^{2}$ of 0.108 and 0.049 , respectively. For the intermediate two periods however, i.e., 2008 to 2009 and 2009 to 2010, the relationship is either zero or weakly

\footnotetext{
${ }^{9}$ These results are available from the authors upon request.
} 
negative. Overall, Figure 3.B. presents inconclusive evidence of the existence of a positive relationship between changes in VaR-levels and changes in short positions.

Next, we shift our focus from univariate to multivariate risk calculations. Figure 4.A. depicts the relationship between relative short positions and systemic risk levels.

\section{$<<<<$ PLACE FIGURE 4.A. AROUND HERE $>>>>$}

The twelve sub-graphs of Figure 4.A. show a fairly consistent picture. All twelve trend lines slope upward, albeit only marginally on some occasions. For all three countries and for all four monthly periods, increases in short positions are associated with simultaneous increases in the financial institutions' systemic risk levels. The results in Figure 4.A. further show that the relationship between short position and systemic risk levels is stronger for some countries and periods than others. The strongest evidence is found in France in June 2010, when individual financial institutions' estimates are clustered quite close around the trend line, and the $\mathrm{R}^{2}$ equals a high level of 0.46. Additionally, in Spain in June 2008 the relationship proves to be rather strong, with an $\mathrm{R}^{2}$ equal to 0.22 . For other periods, however, the results are less convincing. For instance, for France in June 2008 and Spain in June 2007, we find low explanatory power, as evidenced by low $\mathrm{R}^{2} \mathrm{~s}$ in both cases. Despite of these two periods, however, the overall results do suggest the existence of a positive relationship between the multivariate risk and short position levels.

Figures 4.B. and 4.C. present the results regarding whether systemic risks hold for the first differences' data, i.e., is there a relationship between changes in short position and changes in systemic risk?

\section{$<<<$ PLACE FIGURES 4.B. AND 4.C. AROUND HERE $>>>>$}

The first set of four sub-graphs in Figure 4.B. shows annual changes pooled across the three countries. Thus, for each individual year, estimates for France, Italy, and Spain are combined into one graph. Figure 4.C. depicts long-term (four yearly) changes for each of the three countries separately. Therefore, this second set of sub-graphs focuses on within-country changes. Interestingly, all seven sub-graphs in Figures 4.A. and 4.B. show upward sloping trend lines. For 
some sub-graphs, the relationship is quite weak, such as the 2008-2009 and 2010-2011 subperiods in Figure 4.B., where the $\mathrm{R}^{2}$ equals a low value of 0.01. In several sub-graphs however, the explanatory power is substantially higher, with a strongly upward sloping trend line. The subgraph for France in Figure 4.C. is a good example of such more convincing evidence, where the $\mathrm{R}^{2}$ equals 0.34 and the slope parameter equals 0.12. Overall, the results in Figures 4.B. and 4.C. together reinforce the earlier conclusions drawn from Figure 4.A: increases in systemic risk levels tend to coincide with increases in short position levels.

\section{$<<<<$ PLACE FIGURE 5. AROUND HERE $>>>>$}

Figure 5 provides an overview of the two main relationships between risk and short position levels. We distinguish between individual VaRs in the left panel and systemic risks in the right panel of Figure 5. Four-yearly changes are used to study the relationship, and the results for all 45 financial institutions of all three countries are shown together. Both the univariate and multivariate risk trend lines are upward sloping, with a stronger relationship in the multivariate case. This is consistent with the results reported earlier in this section. This evidence also substantiates the findings of Pais and Stork (2012) for a slightly different dataset.

Lastly, as a further robustness test, we changed our systemic risk calculation methodology from assessing intra-country risks to inter-country risks. All systemic risk calculations in this study so far have been based on conditional-co-crash probabilities of financial institutions that are listed on the same exchange. However, such contagion interdependencies also exist between different exchanges, especially within the European Union. Hence, we re-calculated the systemic risks using this adjusted measure, thus using average conditional-co-crash probabilities of financial institutions that are listed on different exchanges. For sake of space, we do not report the results. We find that our conclusions are largely unaffected, albeit slightly weakened. We interpret the outcomes of this robustness test as support for the findings reported. 


\section{Capital Requirements and Short-Selling}

Capital is needed by banks to perform their basic financial intermediation function because a bank may only lend if it meets the capital requirements for each asset it originates. During crises, financial institutions will experience more asset write downs (which are deducted from capital) and may fail to maintain minimum capital ratios, which can lead to a failure (and potential contagion) unless some other investor or the government steps in. The GFC caused major losses for many financial institutions, led to several bankruptcies and forced the restructuring of many US and European banks, which included injections of public capital. This generated a crisis of confidence, as seen in the 2008 runs on wholesale debt markets. As liquidity problems grew, banks had to liquidate assets to meet capital requirements.

In this section, we test our second hypothesis. Short-selling bans are imposed by regulators trying to reduce systemic risk. Therefore, it is a great concern for regulators when short-sellers target financial institutions with the lowest capital buffers, especially in times of crisis. Acharya et al (2012) highlight the contribution of excessive leverage in propagating a crisis, where a financial institution is unable to perform its intermediary function when the value of its equity falls to a sufficiently small fraction of its outstanding liabilities. In good times, a troubled institution may be able to raise new capital, be bought by another institution or face an orderly bankruptcy. However, when aggregate capital (in the financial industry) is low, there are no healthy financial firms able to buy or cover the functions of the insolvent institution, and the consequences of the capital shortage will be felt throughout the financial and real sectors. The government will face the costs of rescuing the failed institutions to prevent a systemic crisis. Consequently, Acharya et al (2012) argue that systemically risky financial institutions are likely to face a large capital shortfall just when the financial sector itself is under distress because no other firm in the system can assume their liabilities. Thus, institutions with very low capital levels will generate the highest systemic risk when the financial sector as a whole is low in capital.

Recall also the models of Brunnermeier and Oehmke (2013) and Liu (2010), in which shortsellers prefer to target financial institutions with weaker capital positions or higher leverage 
because of the higher likelihood of being successful in their price manipulation. Drops in the stock prices triggered by short-sellers will generate a crisis of confidence amongst creditors and investors, which will feedback into the fundamental value of the institution, thereby selfvalidating the lower valuations. Likewise, institutions with low capital buffers and asset losses will find themselves forced into the inefficient liquidation of long-term assets because raising new capital on these circumstance would be too costly; short-sellers aware of this will put further pressure on these institutions and force them to their total unwinding. Banks with low capital requirements are also more exposed to extreme shocks, especially at times of crisis (De Jonghe, 2010).

Figures 6.A., 6.B. and 6.C. provide a rough first assessment of this hypothesis.

<< INSERT FIGURES 6.A., 6.B., AND 6.C. AROUND HERE $>>>$

Figure 6.A. distinguishes between banks (top panel) and other financial institutions (bottom panel), which primarily consist of insurers. The top panel of Figure 6.A. shows that higher capital adequacy ratios for banks tend to coincide with lower short positions over the 2007-2011 period $^{10}$. The parameter that measures the sensitivity of this relationship, as depicted by the trend line in Figure 6.A., equals -2.381 . Hence, for every percentage point rise in the capital adequacy ratio, the short positions on average decrease by 2.38 percentage points. However, this number must be taken with caution because it has limited explanatory power. Other factors are of greater importance, as one would expect.

The lowest capital adequacy ratio is found for Banca Monte dei Paschi di Siena. Between the end of 2007 and the end of 2008, its average capital adequacy ratio equalled a low 5.62\%. Since this time, it has succeeded in increasing this ratio to above eight per cent in 2010. The highest capital adequacy ratio that was measured in our sample was found for Banca Profilo. Between 2009 and 2010 , this bank had a ratio equal to 26.22 per cent, far above regulatory requirements and much

\footnotetext{
${ }^{10}$ We estimate financial institutions' capital buffer as the average of their capital ratio at the end of the previous year and their capital ratio at the end of the current year. As a robustness test, we also ran all calculations in this section with forward- and backward-looking numbers and, thus, with only end-of-previous-year and end-of-currentyear buffers. The results do not change materially, and the conclusions are unaffected.
} 
higher than any of its peers in our sample. As a robustness test, we removed several such 'outliers'. Our previous conclusions are unaffected, and the relationship between the capital adequacy ratio and relative short position remains strongly negative. Next, we move to nonbanks, for which the capital adequacy figures are unavailable. Another metric that reflects the level of leverage of financial institutions is total debt as a percentage of total capital. A higher value of this variable indicates more leverage. This leverage-metric thus has a function opposite that of the capital adequacy ratio used for banks, where a higher value indicates lower leverage. The bottom panel of Figure 6.A. shows that the relationship between this leverage metric and the short selling levels is positive. The upward sloping trend line in the bottom panel indicates that short selling tends to increase with the level of non-bank financial institutions' leverage as well.

A more detailed analysis of the data reveals that April Group was the financial institution with the lowest leverage. In 2010, its debt as a percentage of total capital equalled only $5.48 \%$; by 2011 , this ratio had fallen to $4.25 \%$. In both years, the relative short positions were very low as well, at $0.34 \%$ and $3.30 \%$, respectively. On the other hand, we also find that in some cases very low short positions correspond to financial institutions for which the leverage is much higher. In 2010, the Italian insurer Vittoria Assicurazioni had a total debt as a percentage of total capital equal to 42.78 per cent, while having short positions of only 0.97 per cent. By 2011, this same financial institution's leverage ratio increased to 43.36 per cent, while the relative short positions were still very low, at only 0.71 per cent.

Lastly, Figures 6.B. and 6.C. depict the same relationship between leverage and short selling, but from a slightly different perspective. The relationship is now analysed at different points in time. Overall, the conclusions remain unchanged and are even further reinforced. All trend lines in Figure 6.B. are negative. For the first four months, i.e., June 2007 - June 2010, the explanatory power does not change much as it hovers between three and five per cent. The results for June 2011 appear stronger because the $\mathrm{R}^{2}$ equals a high value of 0.694 , but this finding cannot be compared with previous findings because at the time of writing, only nine institutions had published their end-of-year capital ratio numbers. Thus, for June 2011 the number of observations is much lower. Nevertheless, the relationship is again negative and, thus, in line with previous years. 
Figure 6.C., which shows non-bank financial institutions, confirms the previous results. In four of the five time periods, we find that short positions tend to be higher for insurers with lower capital buffers, although in June 2008 the relationship appears to be zero. These results support the notion that, over time, the weaker insurers are being targeted by short sellers.

\section{Conclusion}

Regulators need to balance the positive effects of short selling in market efficiency and liquidity with its negative effects on market prices at times of market instability. This need is more pressing when ensuring the stability of financial institutions. Banning short-selling cannot make banks' risks disappear or their returns turn instantly positive. However, if short-sellers cause prices to fall beyond their fundamental value and amplify market crashes, increasing the fragility and systemic risks of financial institutions, a ban of short-selling in a time of crisis is justified.

The academic literature usually regards short selling as instrumental to market efficiency and beneficial for price discovery. However, the general public and CEOs (who frequently blame short-sellers for falling stock prices) tend to consider it a damaging form of trading. Regulators have occasionally taken this view and have introduced mechanisms to restrict short-selling. This study looks at the factors that drove market regulators to impose the short-selling bans on financial institutions' stocks during the Global Financial Crisis. Of special interest is determining whether the bans prevented a larger systemic crisis. If the bans on short-selling cause a temporary disruption of market liquidity or efficiency, the impact is likely to be less expensive than the cost of rescuing one or more financial institutions.

This study tests two hypotheses regarding short selling bans and the risks of financial institutions. First, it analyses whether short-selling increases institutions' individual and systemic risks. Second, it tries to determine whether short-sellers were targeting the most undercapitalised institutions because the downward price pressure is more likely to result in profits when the institutions under attack have the lowest capital ratios. The paper uses EVT to estimate the effect of short selling on the individual and systemic risk of financial institutions in three European 
countries (France, Italy and Spain). These three countries were the target of a short-selling ban imposed in August 2011.

Regulators argue that short-sellers deliberately drive down the prices of financial institutions' stocks beyond fundamental values to generate panic selling and further depress prices. A decrease in the market value of a bank's stock price affects the confidence of current and future creditors and investors and the institution's ability to raise more capital and debt, increasing leverage and thus negatively affecting its stock price even further. This strategy renders large profits from closing the short position at a lower price. At the same time, however, it may destabilise the market if it increases contagion risks across the financial industry.

Our results show that there is a positive relationship between daily changes in short-selling volume and daily changes in both univariate and systemic risks for institutions in the ban countries. This relationship is stronger for short-selling and systemic risk, which gives support to regulatory actions aimed at preventing systemic crises. The results also show that lower capital adequacy ratios for banks (or higher leverage for insurance companies) tend to correspond with larger short positions.

These results are comparable to other findings that short selling can at times amplify market crashes and can be an instrument for price manipulation. Feedback effects between market prices and real investment decisions heighten the vulnerability of the financial system, particularly for financial institutions that have to meet capital requirements and depend on public confidence.

The recent financial crisis stresses the need to properly measure and understand banking crises and systemic risk because events that increase these risks impose high welfare costs on the economy. Regulators have been broadly criticised because short-selling bans can potentially affect market efficiency. However, the repercussion of the bans on market efficiency is only one piece of the impact of such regulatory actions: the large costs of bailing out one or more banks are a greater worry for regulators. If short-sellers cause prices to fall beyond fundamentals and increase the probability of a bank crashing and/or the contagion risks between financial institutions, then a ban of short-selling at times of crisis could be justified. 


\section{References}

Ackert, L.F. and G. Athanassakos, 2005, "The relationship between short interest and stock returns in the Canadian market", Journal of Banking \& Finance, 29(7), 1729-1749.

Acharya, V., Enge, R. and M. Richardson, 2012, "Capital shortfall: A new approach to ranking and regulating systemic risks", American Economic Review: Papers \& Proceedings 2012, 102(3), 59-64.

Autore, D. M, Billingsley, R.S. and T. Kovacs, 2011, "The 2008 short sale ban: Liquidity, dispersion of opinion, and the cross-section of returns of US financial stocks', Journal of Banking \& Finance, 35(9), 2252-2266.

Bank for International Settlements, Committee on Global Financial System, 2011, "The impact of sovereign credit risk on bank funding conditions". July 2011.

Battalio, R., Mehran, H. and Schultz, P., 2011, "Market declines: Is banning short selling the solution?", Federal Reserve Bank of New York Staff Reports, Staff Report no 518, September 2011.

Beber, A.and M. Pagano, 2013, "Short-selling bans around the world: Evidence from the 2007-09 Crisis", Journal of Finance, 68(1), 343-381.

Bocher, J., Engelberg, J. and A. Reed, 2008, “The long-short wars: Evidence of end-of-year price manipulation by short Sellers". Available at http://ssrn.com/abstract=1364835.

Boehmer, E., Jones, C.M. and X. Zhang, 2013, "Shackling short sellers: The 2008 shorting ban". The Review of Financial Studies, 26(6), 1363-1400.

Bris, A., Goetzmann, W.N. and N. Zhu, 2007, "Efficiency and the bear: Short sales and markets around the world", Journal of Finance, 62(3), 1029-1079.

Brunnermeier, M.K and M. Oehmke, 2013, "Predatory short-selling", Review of Finance, forthcoming.

Brunnermeier, M.K and H. Pendersen, 2005, "Predatory trading", Journal of Finance, 6(4), 1825-1863. 
Data Explorers, 2011, “Securities Lending Review, Q2 2011.

De Haan, L., Jansen, D. W., Koedijk, K. and C.G. de Vries, 1994, "Safety first portfolio selection, extreme value theory and long run asset risks', in Galambos, J., Lechner, J. and Simiu, E. (eds), Extreme Value Theory and Applications (Dordrecht, the Netherlands: Kluwer Press), 471-87.

De Jonghe, O. 2010, "Back to the basics in banking? A micro-analysis of banking system stability" Journal of Financial Intermediation, 19 (3), pp. 387-417

Diamond, D.W. and P.H. Dybvig, 1983, "Bank runs, deposit insurance, and liquidity”, Journal of Political Economy, 91, 401-419.

Diamond, D.W. and R.E. Verrecchia, 1987, "Constraints on short-selling and asset price adjustment to private information", Journal of Financial Economics, 18, 277-311.

Duffy, G.T., 2008, “A remedy for short-selling manipulation”, retrieved from http://www.sec.gov/comments/s7-30-08/s73008-35.pdf.

Goldstein, I. and A. Guembel, 2008, "Manipulation and the allocational role of prices", Review of Economic Studies, 75(1), 133-164.

Gruenewald, S.N., Wagner, A.F. and R.H. Weber, 2010, "Short selling regulation after the financial crisis - first principles revisited", International Journal of Disclosure \& Governance, 7, 108-135

Hartmann, P., Straetmans, S. and de C.G. Vries, 2004, “Asset market linkages in crisis periods”, The Review of Economics and Statistics, 86, 313-26.

Henry, T.R and J.L. Koski, 2010, "Short-selling qround seasoned equity offerings", Review of Financial Studies, 23(12), 4389-4418.

Hill, B., 1975,"A simple general approach to inference about the tail of a distribution", The Annals of Statistics, 3, 1163-73. 
Khanna, N., and R.D. Mathews, 2012, "Doing battle with short sellers: The conflicted role of blockholders in bear raids”, Journal of Financial Economics, 106(20, 229-246.

Liu, X., 2010, “Predatory short-selling and self-fulfilling crises: When Morris-Shin meets DiamondDybvig". Available at SSRN: http://ssrn.com/abstract=1780240

Marsh, I. and R. Payne, 2012, "Banning short-sales and market quality: the UK experience", Journal of Banking \& Finance, 36(7), 1975-1986.

Miller, E.M. , 1977, "Risk, uncertainty and divergence of opinion”, Journal of Finance, 32, 1151-1168.

Misra, V., Lagi, M. and Y. Bar-Yam, 2012, "Evidence of market manipulation in the financial crisis”. arXiv:1112.3095, December 13, 2011 (Addendum: January 4, 2012).

Ozdenoren, E. and K. Yuan, 2008, "Feedbacks effects and asset prices”, Journal of Finance, 63(4), 19391975

Pais, A. and P.A. Stork, 2011, "Contagion risk in the Australian banking and property sectors", Journal of Banking and Finance, 35(3), 681-697.

Pais, A. and P.A. Stork, 2012, "Short-selling bans and contagion risk", Journal of Financial Transformation, issue \#35, 109-121, Zicklin-Capco Institute Paper Series in Applied Finance.

Saffi, P. and K. Sigurdsson, 2011, "Price efficiency and short-selling", Review of Financial Studies, 24(3), 821-852.

Shkilko, A., Van Ness, B. and R. Van Ness, 2012, "Short selling and intraday price pressures", Financial Management, 41(2), 345-370.

Straetmans, S., Verschoor, W. and C. Wolff, 2008, "Extreme US stock market fluctuations in the wake of 9/11", Journal of Applied Econometrics, 23, 17-42.

Subrahmanyam, A., and S. Titman, 2001, "Feedback from stock prices to cash flows", Journal of Finance, 56, 2389-2413. 
Figure 1. Short Positions Over Time.
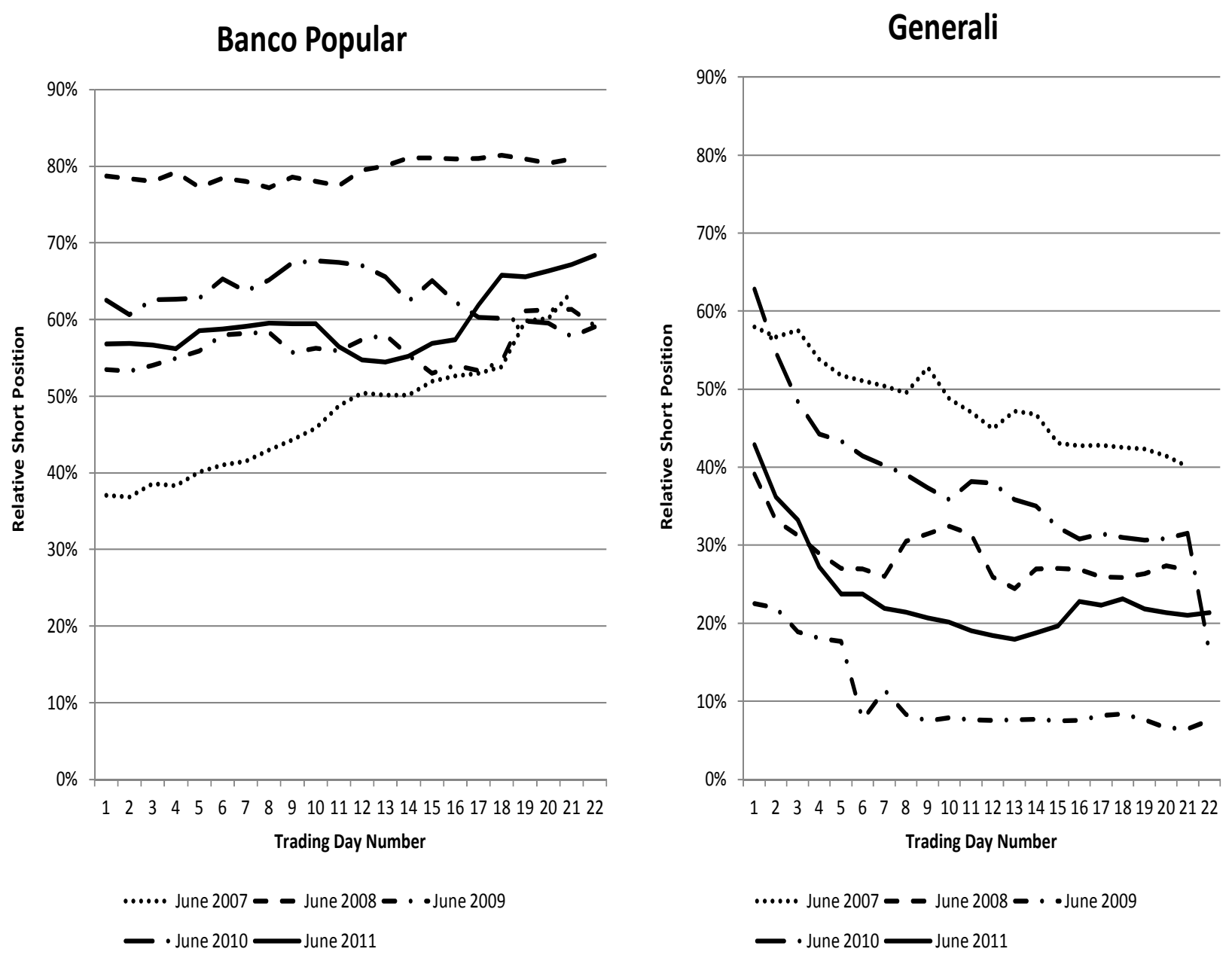

Figure 1 depicts changes in relative short positions (defined in the Data Description section) for Banco Popular and Generali for five different months. Within-month trading day numbers are shown on the horizontal axes. 


\section{Figure 2. Value at Risk over Time.}
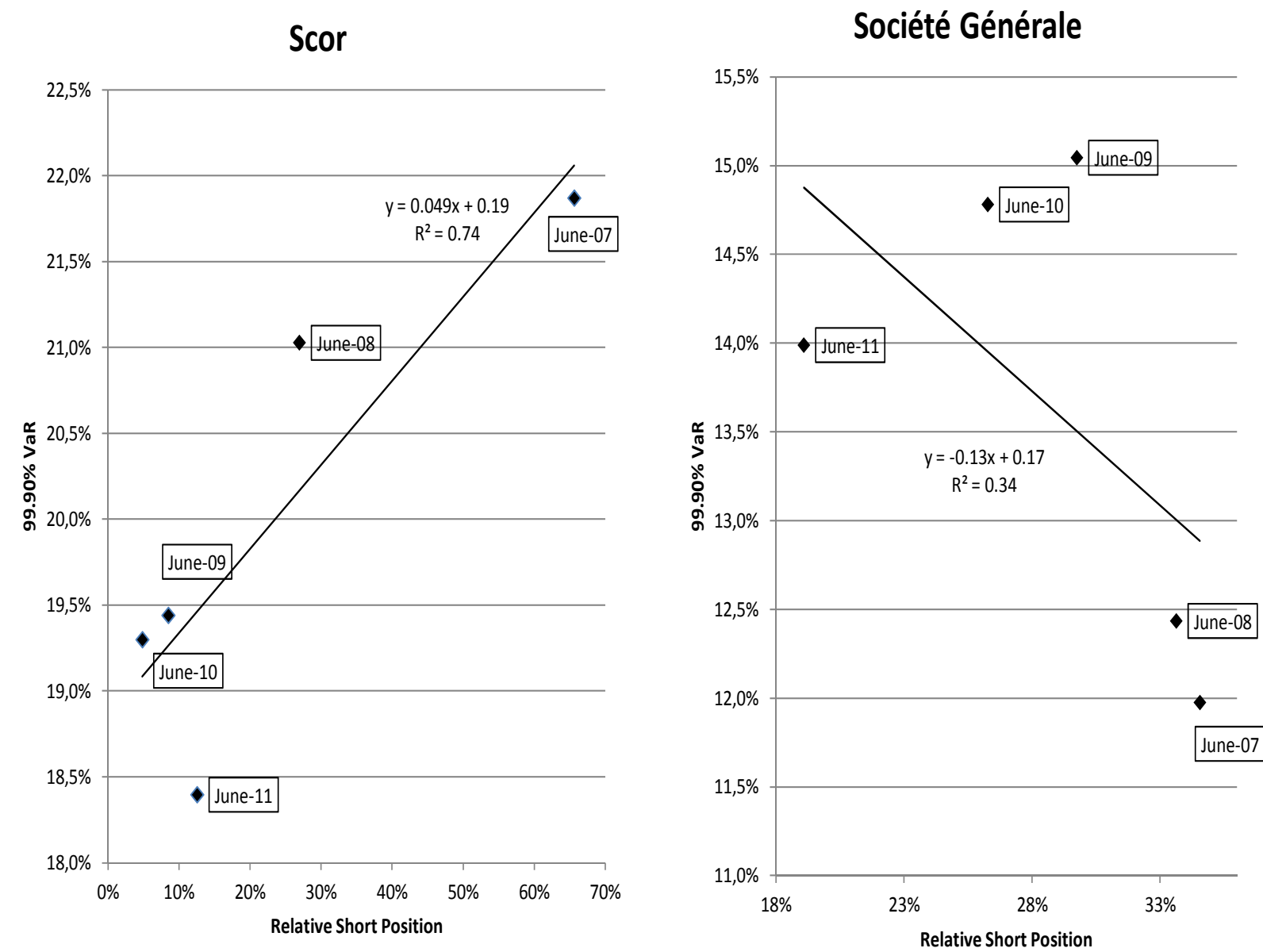

Figure 2 depicts the relationship between relative short positions (defined in the Data Description section) and 99.90 per cent VaR levels for the French financial institutions Scor and Société Générale. Using OLS, a linear regression is estimated, and the resulting trend line is drawn. The VaR is calculated per the middle trading day of each calendar month that is reported in Figure 2, i.e., 15 June 2007, 16 June 2008, 15 June 2009, 15 June 2010, and 16 June 2011. VaR is estimated in the following way:

$\operatorname{VaR}=x_{k+1}\left(\frac{k}{M p}\right)^{\hat{\gamma}}$ in which $\hat{\gamma}=\frac{1}{k} \sum_{j=1}^{k} \ln \left(\frac{x_{j}}{x_{k+1}}\right)$

where $\hat{\gamma}$ is the tail shape estimator and $x_{j}$ is the $j^{\text {th }}$ order statistic, i.e., $x_{j} \geq x_{j-1}$ for $j=2, . ., M$, in which $M$ equals the number of observations. For the periods to 15 June 2007, 16 June 2008, 15 June 2009, 15 June 2010 and 16 June 2011, the number of observations $M$ equals 1,612, 1,873, 2,133, 2,394, and 2,655, respectively. The number of order statistics used in the estimation $k$ depends on the length of the period analysed. For the periods to 15 June 2007, 16 June 2008, 15 June 2009, 15 June 2010 and 16 June 2011, the number of order statistics $k$ is set equal to $40,43,46,49$ and 52, respectively. The exceedance probability (or significance level) $p$ is set equal to $0.1 \%$. 
Figure 3.A. Relationship between VaR and Short Position.
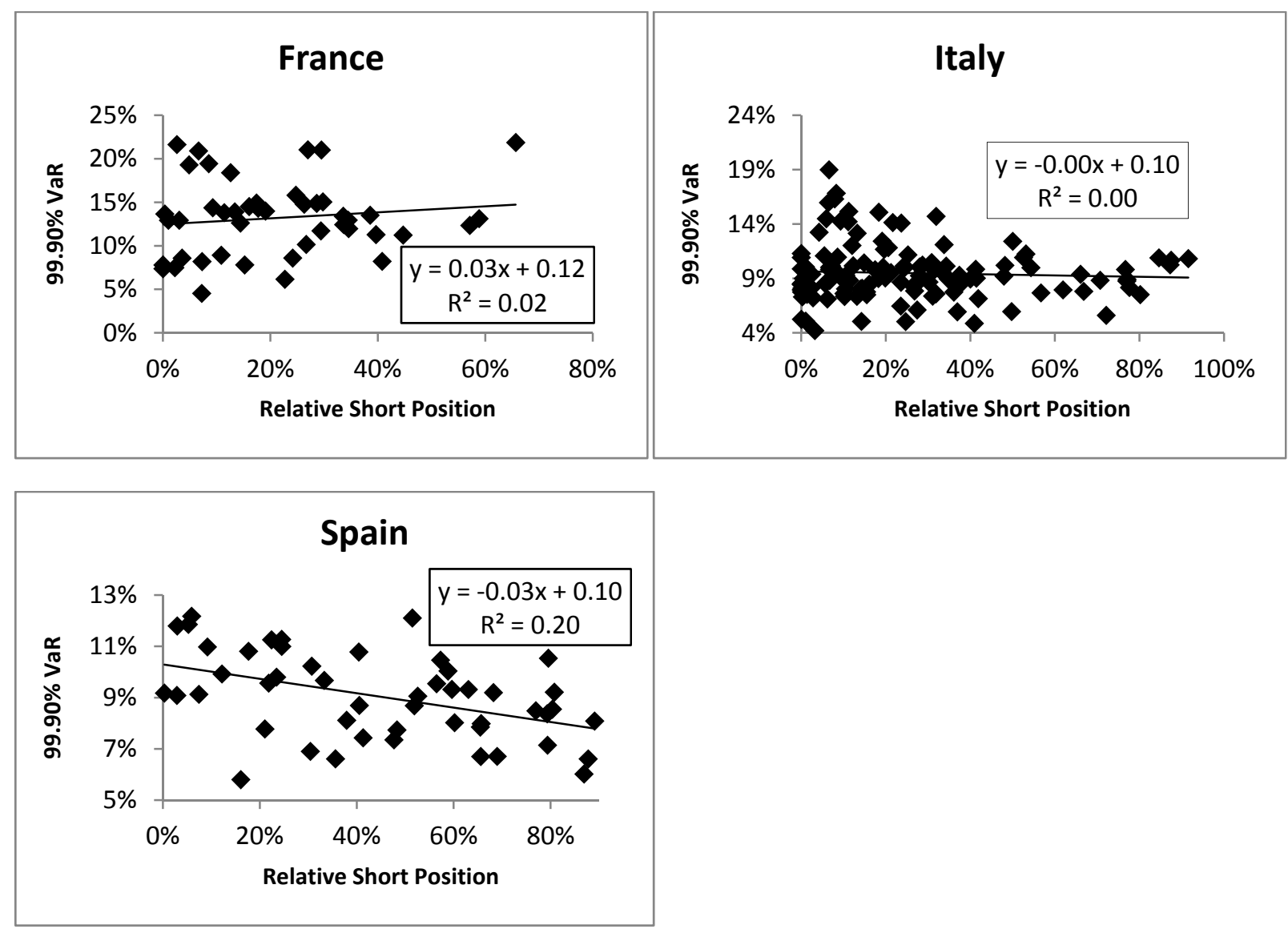

Figure 3.A. shows, for each of the three countries and for all months of June of the years $2007-2011$, the relationship between $99.90 \%$ VaR-levels and relative short positions. The results for France, Italy and Spain are depicted separately. Each observation (i.e., marker) in Figure 3.A. represents the estimates for one individual financial institution at one moment in time. Using OLS, a linear trend line is estimated and drawn, and the associated $\mathrm{R}^{2}$ is provided. The measurement of the relative short position is defined in the Data Description section. The VaR is calculated per the middle trading day of the calendar month as follows: $\operatorname{VaR}=x_{k+1}\left(\frac{k}{M p}\right)^{\hat{\gamma}}$ in which $\hat{\gamma}=\frac{1}{k} \sum_{j=1}^{k} \ln \left(\frac{x_{j}}{x_{k+1}}\right)$ where $\hat{\gamma}$ is the tail shape estimator, and $x_{j}$ is the $j^{\text {th }}$ order statistic, i.e., $x_{j} \geq x_{j-1}$ for $j=2, . ., M$, in which $M$ equals the number of observations. For the periods to 15 June 2007, 16 June 2008, 15 June 2009, 15 June 2010 and 16 June 2011, the number of observations $M$ equals 1,612, 1,873, 2,133, 2,394, and 2,655, respectively. The number of order statistics used in the estimation $k$ depends on the length of the period analysed. For the periods to 15 June 2007, 16 June 2008, 15 June 2009, 15 June 2010 and 16 June 2011, the number of order statistics $k$ is set equal to $40,43,46,49$ and 52, respectively. The exceedance probability (or significance level) $p$ is set equal to $0.1 \%$. 
Figure 3.B. Relationship between changes in Short Position and changes in VaR.
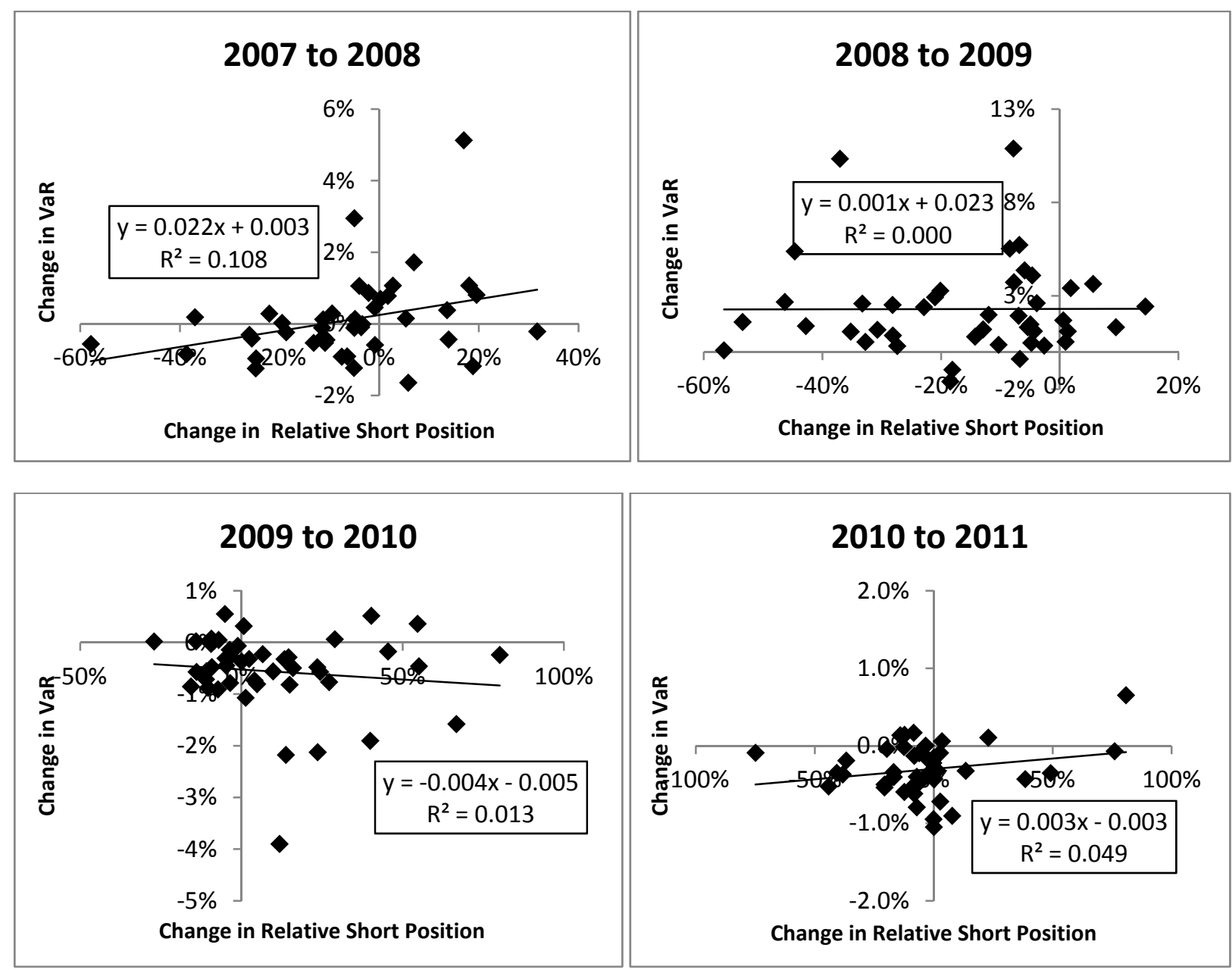

Figure 3.B. shows the relationship between changes in $99.90 \%$ VaR-levels and changes in relative short positions. These changes are measured and depicted over four separate subperiods: June 2007 - June 2008, June 2008 - June 2009, June 2009 - June 2010, and June 2010 - June 2011. Per period, all estimates for France, Italy and Spain are combined into one of the four figures in Figure 3.B. A linear trend line is estimated and drawn using OLS, and the associated $\mathrm{R}^{2}$ is provided. The relative short position is defined in the Data Description section. The VaR is calculated per the middle trading day of the calendar month: $\operatorname{VaR}=x_{k+1}\left(\frac{k}{M p}\right)^{\hat{\gamma}}$ in which $\hat{\gamma}=\frac{1}{k} \sum_{j=1}^{k} \ln \left(\frac{x_{j}}{x_{k+1}}\right)$ where $\hat{\gamma}$ is the tail shape estimator, and $x_{j}$ is the $j^{\text {th }}$ order statistic, i.e., $x_{j} \geq x_{j-1}$ for $j=2, . ., M$, in which $M$ equals the number of observations. For the periods to 15 June 2007, 16 June 2008, 15 June 2009, 15 June 2010 and 16 June 2011, the number of observations $M$ equals 1,612, 1,873, 2,133, 2,394, and 2,655, respectively. The number of order statistics used in the estimation $k$ depends on the length of the period analysed. For the periods to 15 June 2007, 16 June 2008, 15 June 2009, 15 June 2010 and 16 June 2011, the number of order statistics $k$ is set equal to $40,43,46,49$ and 52, respectively. The exceedance probability (or significance level) $p$ is set equal to $0.1 \%$. 
Figure 4.A. Relationship between Short Position and Systemic Risk.
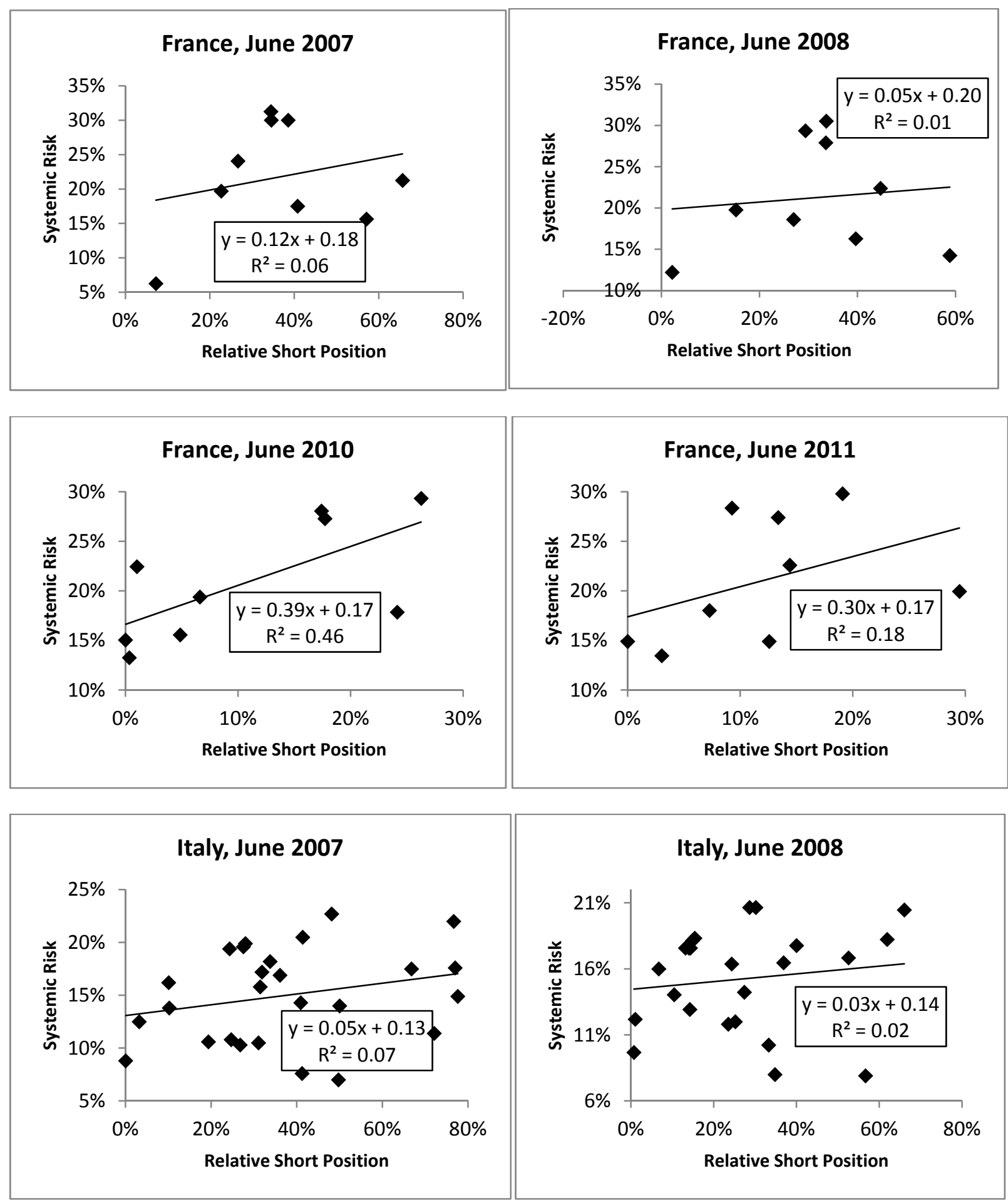

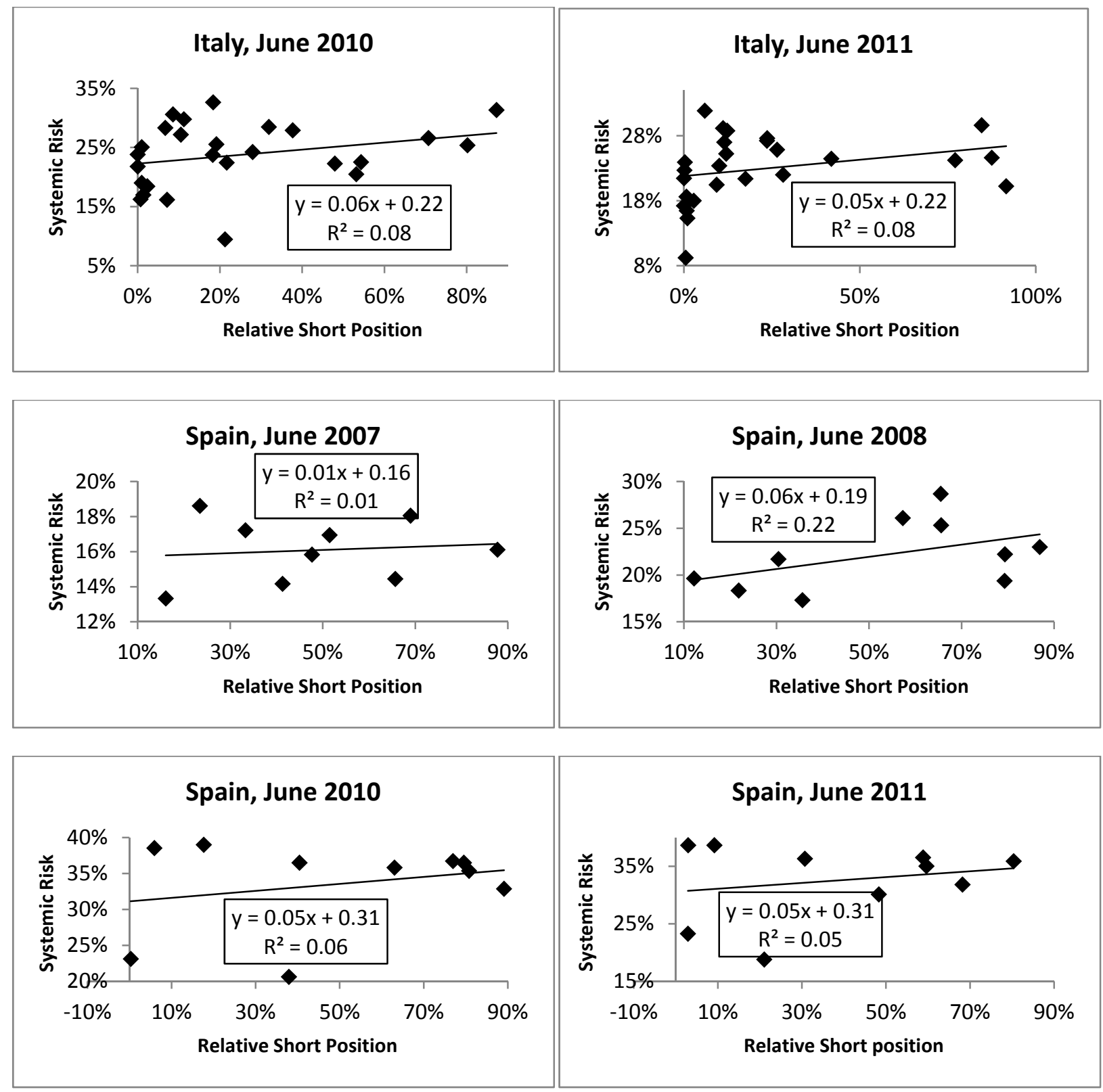

Figure 4.A. depicts the relationship between the relative short position (defined in the Data Description section) and systemic risk. For each country separately for the middle trading date of the calendar months of June 2007, June 2008, June 2010, and June 2011, systemic risk levels are calculated for all financial institutions within that country. The results for June 2009 are not reported here to save space, as they contain little additional information. For each financial institution, conditional-co-crash (CCC) probability estimates are averaged across all financial institutions within the same country. The CCC probability estimates are calculated in the following way:

$C C C=2-\frac{1}{k} \sum_{t=1}^{M} I\left\{\left(v_{i t}>x_{i, M-k}\right) \cup\left(v_{m t}>x_{m, M-k}\right)\right\}$

where $v_{i t}$ denotes the percentage return of stock $i$ at time t, with $i=1, . ., S$ and $t=1, . ., M$, in which $S$ equals the number of stocks and $M$ equals the number of observations. For the periods to 15 June 2007, 16 June 2008,15 June 2009, 15 June 2010 and 16 June 2011, the number of observations $M$ equals 1,612, 1,873, 2,133, 2,394, and 2,655, respectively. The number of order statistics used in the estimation $k$ depends on the length of the period analysed. For the periods to 15 June 2007, 16 June 2008, 15 June 2009, 15 June 2010 and 16 June 2011, the number of order statistics $k$ is set equal to $40,43,46,49$ and 52, respectively. 
Figure 4.B. Relationship between annual changes in short positions and systemic risks.
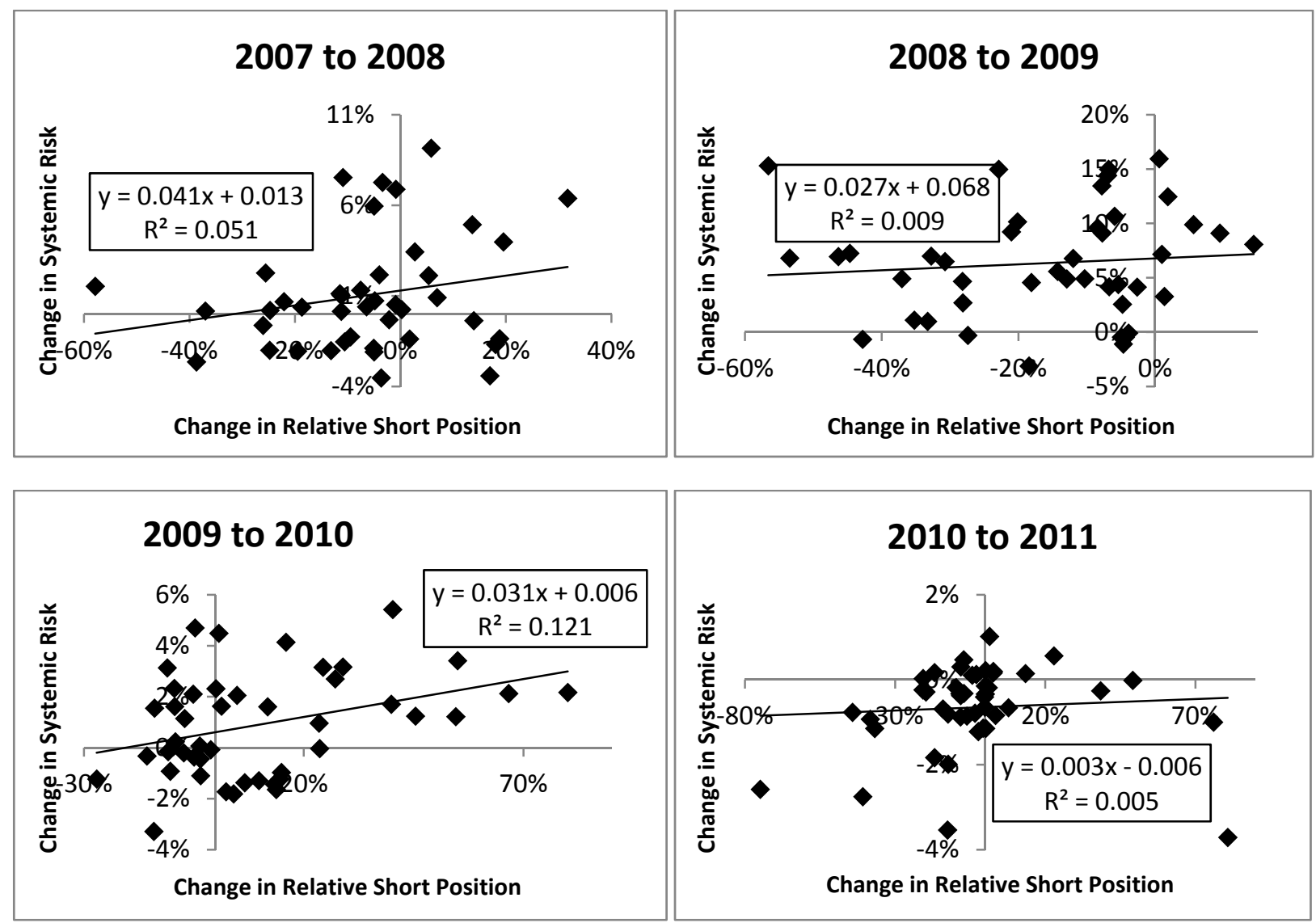

Figure 4.B. depicts the relationship between annual changes in relative short positions (defined in the Data Description section) and annual changes in systemic risks. These changes are measured and depicted over four separate subperiods: June 2007 - June 2008, June 2008 - June 2009, June 2009 - June 2010, and June 2010 - June 2011. Risks are estimated for the middle trading date of the respective calendar month. Per period, all estimates for France, Italy and Spain are combined into one of the four panels of Figure 4.B. A linear trend line is estimated and drawn using OLS, and the associated $\mathrm{R}^{2}$ is provided. For each financial institution, conditional-co-crash (CCC) probability estimates are averaged across all financial institutions within the same country. The CCC probability estimates are calculated in the following way:

$C C C=2-\frac{1}{k} \sum_{t=1}^{M} I\left\{\left(v_{i t}>x_{i, M-k}\right) \cup\left(v_{m t}>x_{m, M-k}\right)\right\}$

where $v_{i t}$ denotes the percentage return in of stock $i$ at time t, with $i=1, . ., S$ and $t=1, . ., M$, in which $S$ equals the number of stocks and $M$ equals the number of observations. For the periods to 15 June 2007 , 16 June 2008, 15 June 2009, 15 June 2010 and 16 June 2011, the number of observations $M$ equals 1,612, $1,873,2,133,2,394$, and 2,655, respectively. The number of order statistics used in the estimation $k$ depends on the length of the period analysed. For the periods to 15 June 2007, 16 June 2008, 15 June 2009, 15 June 2010 and 16 June 2011, the number of order statistics $k$ is set equal to 40, 43, 46, 49 and 52 , respectively. 
Figure 4.C. Relationship Four-Yearly Changes in Short Positions and Systemic Risks.
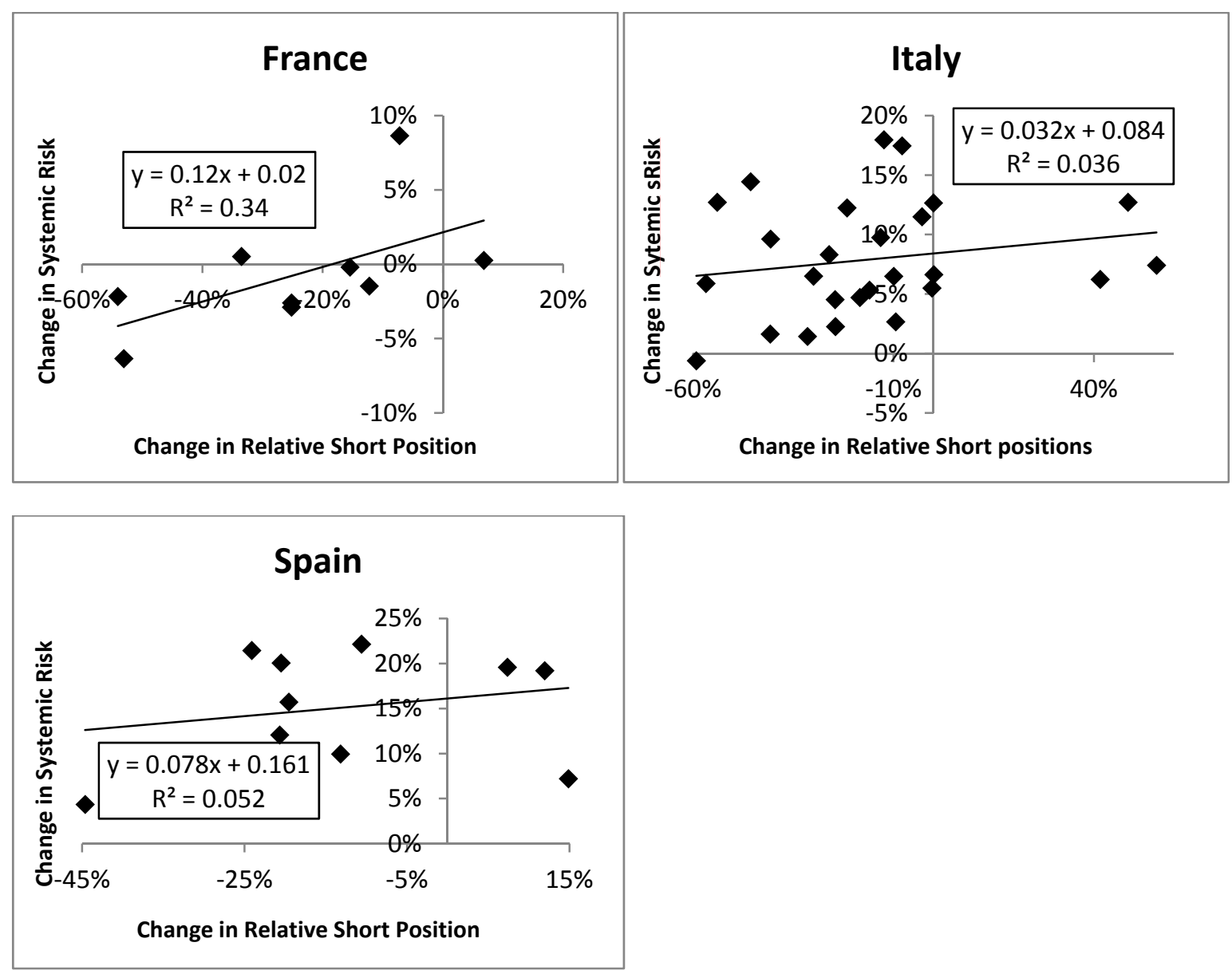

Figure 4.C. depicts the relationship between changes in relative short positions (defined in the Data Description section) and changes in systemic risks. Risks are measured per the middle trading date of the respective calendar month. Changes are measured over the period June 2007 - June 2011. Within each individual country, all estimates are combined into one of the three panels of Figure 4.C. A linear trend line is estimated and drawn using OLS, and the associated $\mathrm{R}^{2}$ is provided. For each financial institution, conditional-co-crash (CCC) probability estimates are averaged across all financial institutions within the same country. The CCC probability estimates are calculated in the following way:

$C C C=2-\frac{1}{k} \sum_{t=1}^{M} I\left\{\left(v_{i t}>x_{i, M-k}\right) \cup\left(v_{m t}>x_{m, M-k}\right)\right\}$

where $v_{i t}$ denotes the percentage return of stock $i$ at time t, with $i=1, . ., S$ and $t=1, . ., M$, in which $S$ equals the number of stocks and $M$ equals the number of observations. For the periods to 15 June 2007, 16 June 2008, 15 June 2009, 15 June 2010 and 16 June 2011, the number of observations $M$ equals 1,612, $1,873,2,133,2,394$, and 2,655, respectively. The number of order statistics used in the estimation $k$ depends on the length of the period analysed. For the periods to 15 June 2007, 16 June 2008, 15 June 2009, 15 June 2010 and 16 June 2011, the number of order statistics $k$ is set equal to 40, 43, 46, 49 and 52 , respectively. 
Figure 5. Relationship between Changes in Short Positions and Risks.
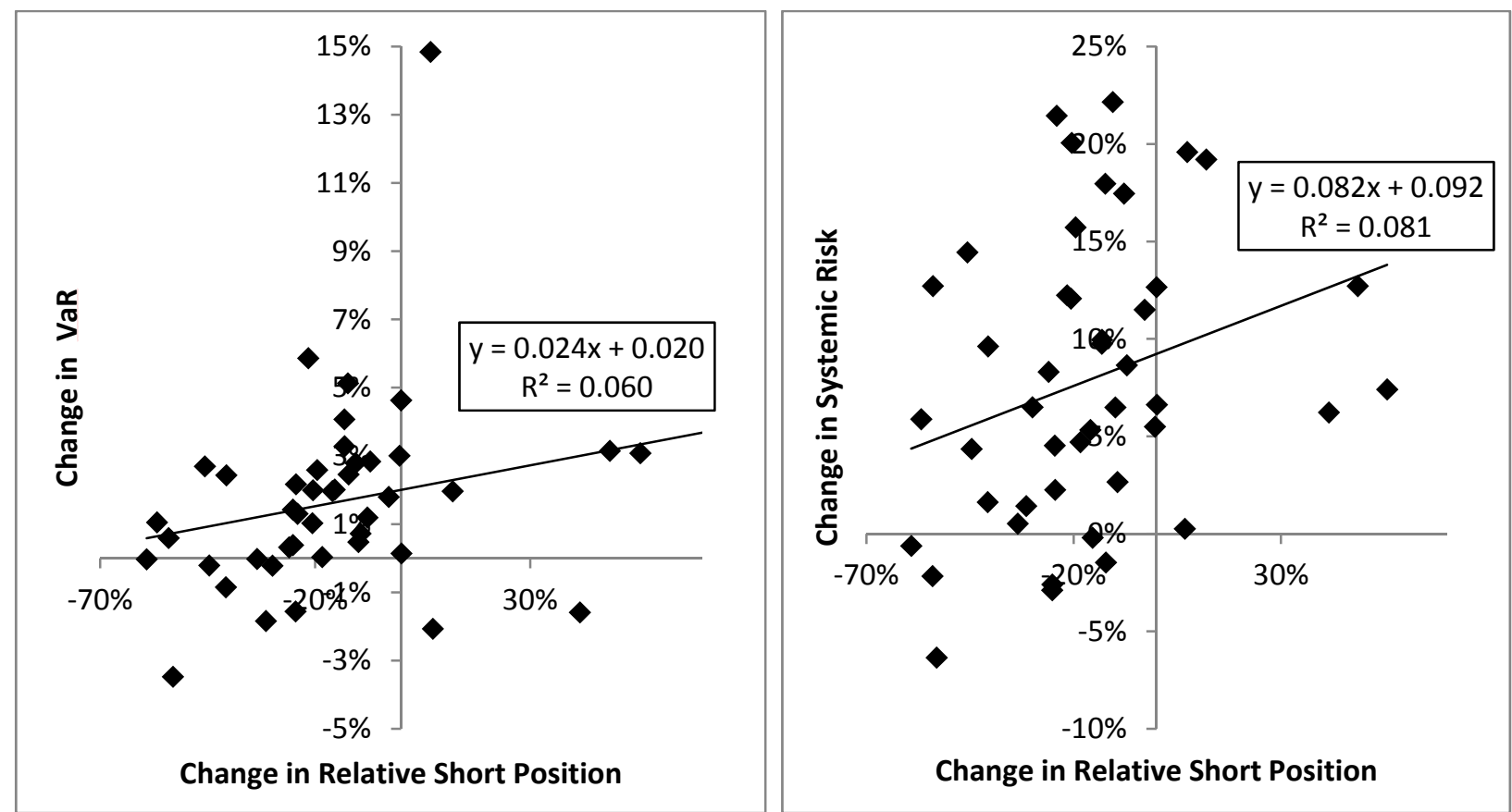

Figure 5 depicts the relationship between changes in relative short positions (defined in the Data Description section) and in systemic risks. Changes are measured over the period June 2007 - June 2011. Risks are calculated for 15 June 2007 and 16 June 2011. Both panels in Figure 5 depict the estimates for all three countries together. A linear trend line is estimated and drawn using OLS, and the associated $\mathrm{R}^{2}$ is provided. For the definitions of $\mathrm{VaR}$ and systemic risk, we refer to the definitions under Figures 3.A. and 4.A., respectively. 
Figure 6.A. Relationship between Short Selling Levels and Leverage Ratios

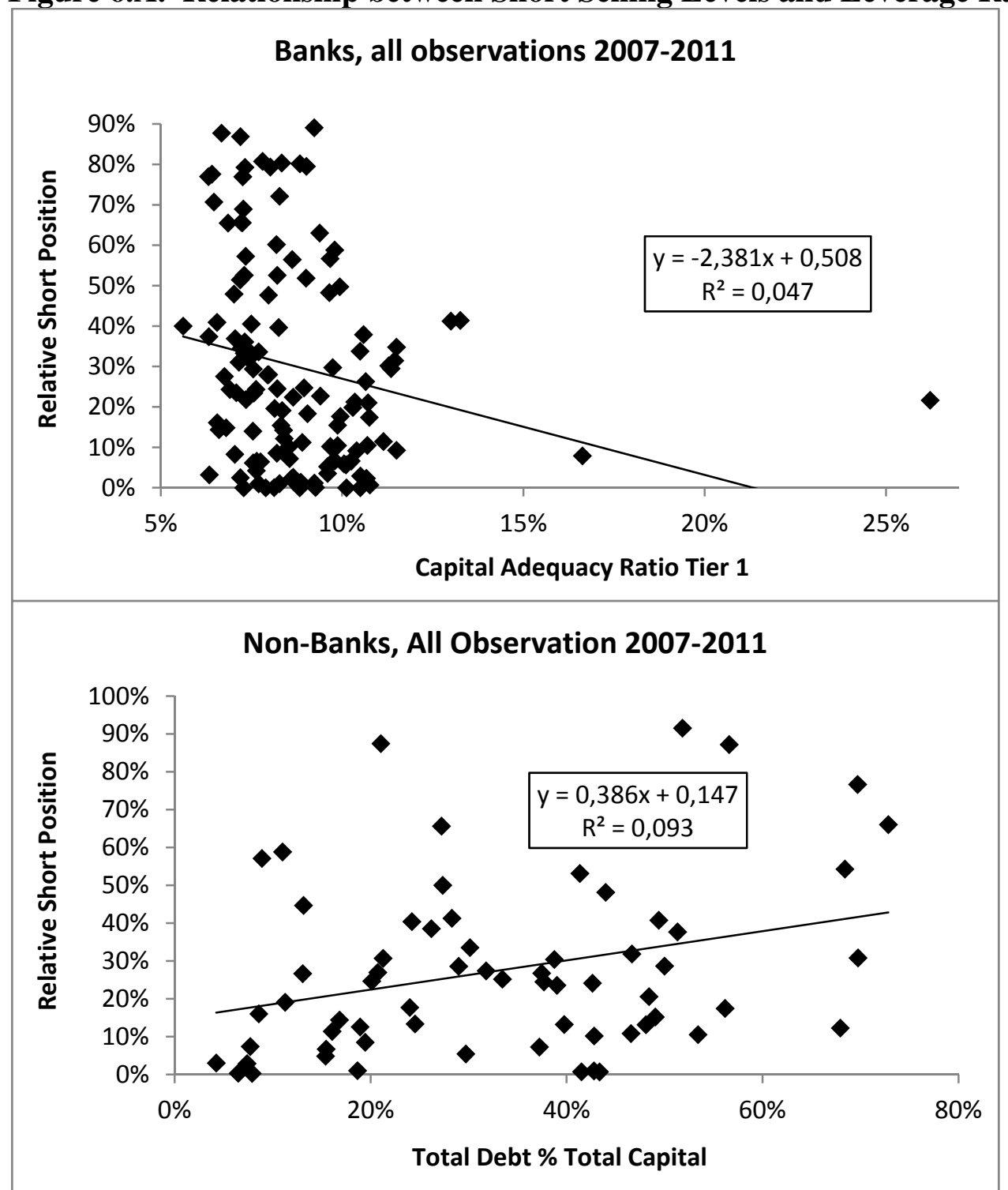

Figure 6.A. distinguishes two different samples. The top panel shows, for all 30 available banks in the sample, the relationship between the 'capital adequacy ratio tier 1' and relative short selling positions (defined in the Data Description section). The capital adequacy ratio Tier 1 is defined by Datastream as the ratio of Tier 1 Capital to total risk-weighted assets, calculated in accordance with banking regulations and expressed as a percentage. Tier 1 capital includes common shareholders' equity and qualifying preferred stock, less goodwill and other adjustments. For each observation of the capital adequacy ratio, we use the average of this ratio per the end of the previous year and per the end of the current year.

The bottom panel depicts, for all 13 available non-bank financial institutions in the sample, the relationship between relative short selling positions and 'total debt as a percentage of total capital' (or debt ratio), which is defined by Datatream as (Long Term Debt + Short Term Debt \& Current Portion of Long Term Debt) / (Total Capital + Short Term Debt \& Current Portion of Long Term Debt) * 100. For each observation of the debt ratio, we use the average of this ratio per the end of the previous year and per the end of the current year. 
Figure 6.B. Relationship between Banks’ Capital Adequacy Ratio and Short Positions

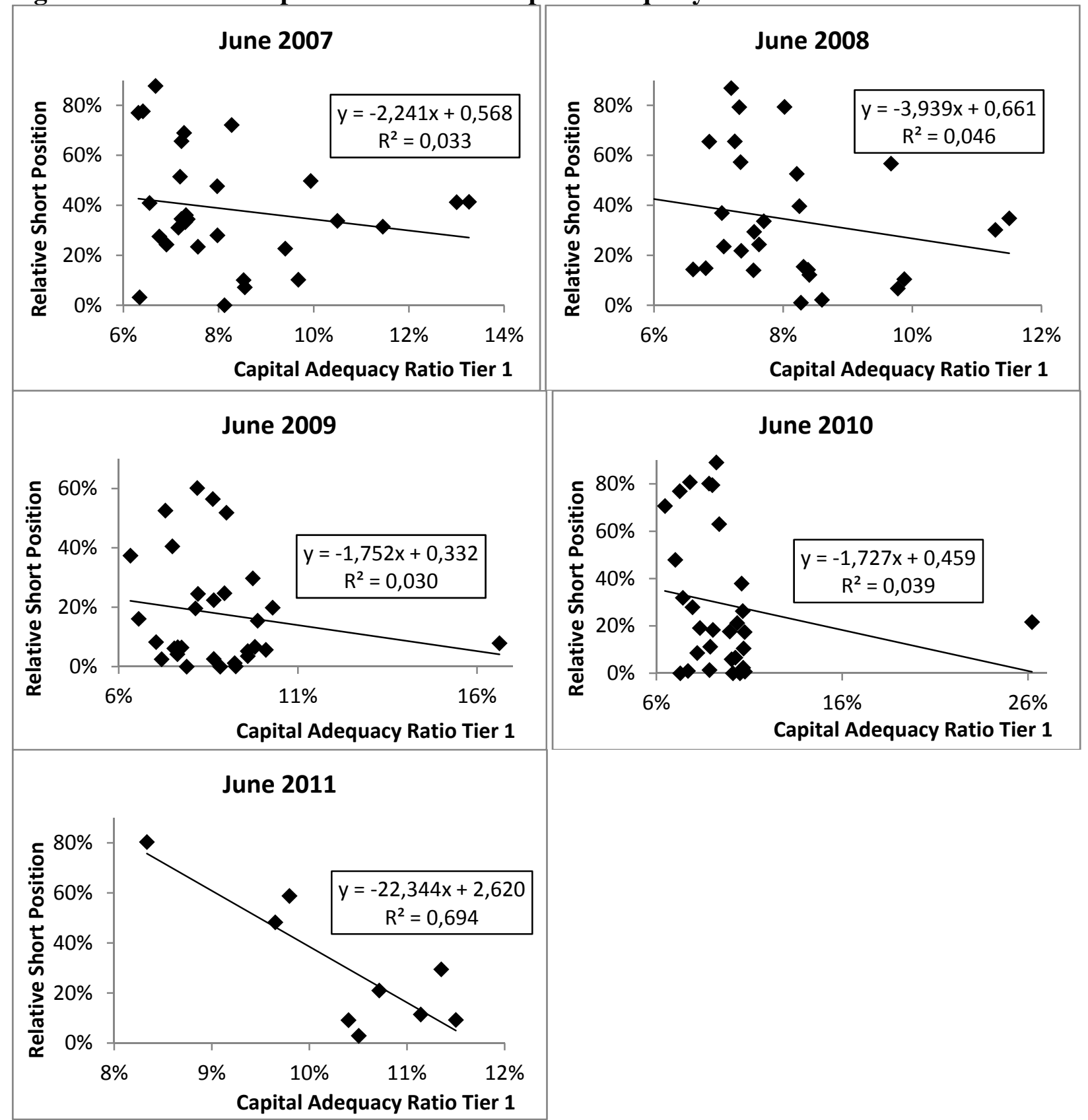

Figures 6.B. and 6.C. show for all available banks (in 6.B.) and non-bank financial institutions (in 6.C.) in the sample the relationship between capital levels and relative short selling positions (defined in the Data Description section) for five different moments, i.e., June 2007 - June 2011. The Tier 1 capital adequacy ratio is defined by Datastream as the ratio of Tier 1 Capital to total risk-weighted assets, calculated in accordance with banking regulations and expressed as a percentage. Tier 1 capital includes common shareholders' equity and qualifying preferred stock, less goodwill and other adjustments. The 'total debt as a percentage of total capital' (or: debt ratio) is defined by Datatream as (Long Term Debt + Short Term Debt \& Current Portion of Long Term Debt) / (Total Capital + Short Term Debt \& Current Portion of Long Term Debt) * 100. For each observation of both the capital adequacy ratio and the debt ratio, we use the average of this ratio per the end of the previous year and the that measured per the end of the current year. 
Figure 6.C. Relationship of Non-Banks' Debt as \% of Total Capital and Short Positions

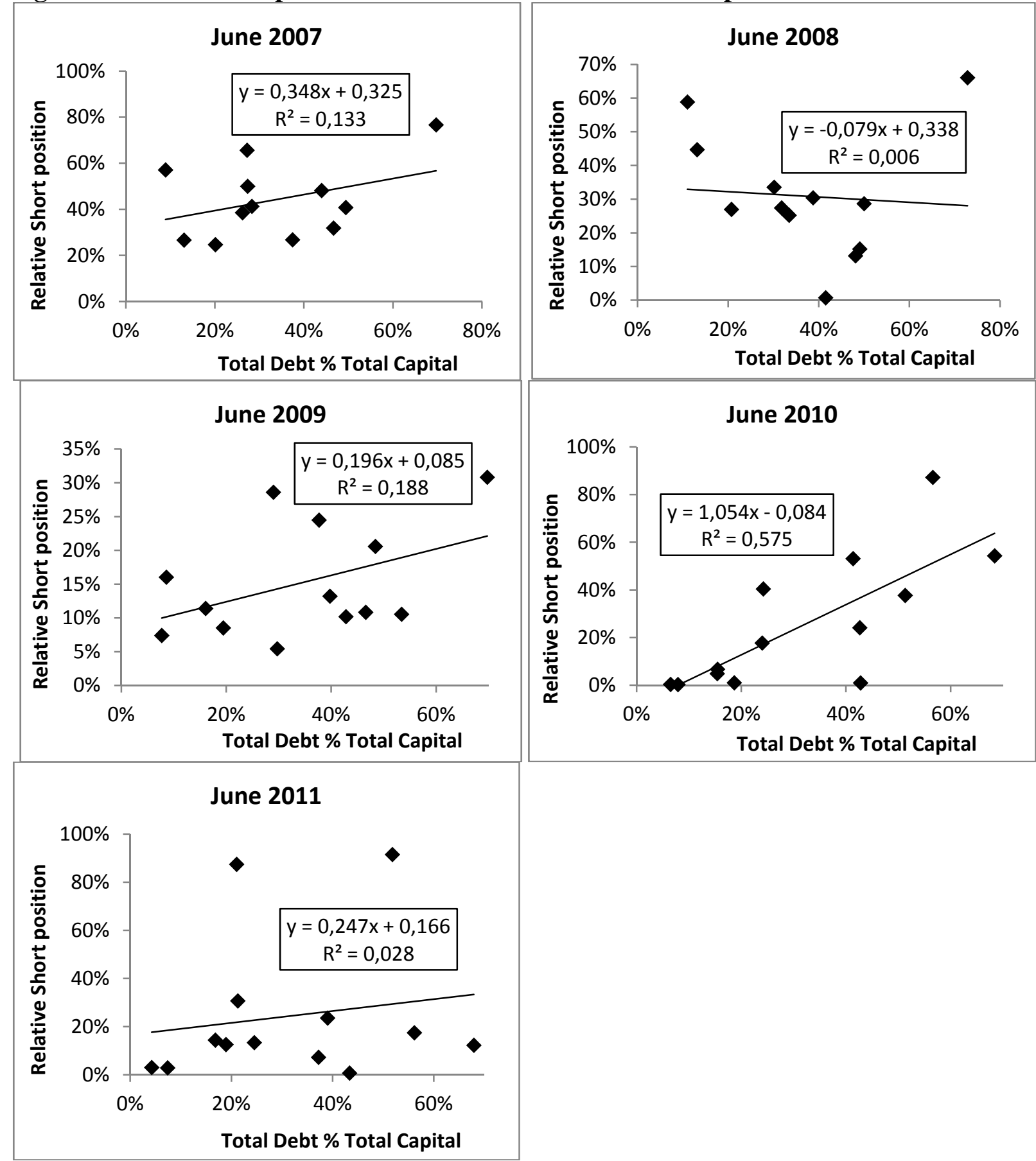


Table 1. Basic Statistics of Financial Institutions' Return Series.

\begin{tabular}{|c|c|c|c|c|c|c|c|c|}
\hline & Financial institution & Average & Min. & Max. & Avg.Ann. & St.Dev. & Skew & Kurt. \\
\hline \multirow{9}{*}{ 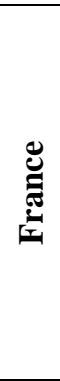 } & AXA & $0.030 \%$ & $-18.41 \%$ & $21.87 \%$ & $7.63 \%$ & $3.00 \%$ & 0.68 & 7.15 \\
\hline & BNP Paribas & $0.042 \%$ & $-17.24 \%$ & $20.90 \%$ & $10.70 \%$ & $2.63 \%$ & 0.70 & 9.54 \\
\hline & $\mathrm{CIC}^{\prime} \mathrm{A}^{\prime}$ & $0.019 \%$ & $-8.37 \%$ & $11.06 \%$ & $4.82 \%$ & $1.45 \%$ & 0.83 & 7.64 \\
\hline & CNP Assurances & $0.044 \%$ & $-13.45 \%$ & $11.00 \%$ & $11.30 \%$ & $1.84 \%$ & 0.16 & 3.79 \\
\hline & April & $0.025 \%$ & $-37.91 \%$ & $13.63 \%$ & $6.30 \%$ & $2.26 \%$ & -1.73 & 31.81 \\
\hline & Euler Hermes & $0.047 \%$ & $-15.14 \%$ & $15.75 \%$ & $11.93 \%$ & $2.25 \%$ & 0.34 & 5.81 \\
\hline & Natixis & $0.028 \%$ & $-17.49 \%$ & $38.81 \%$ & $7.18 \%$ & $2.95 \%$ & 1.45 & 20.98 \\
\hline & Scor SE & $-0.012 \%$ & $-30.39 \%$ & $21.01 \%$ & $-2.98 \%$ & $2.84 \%$ & -0.48 & 15.65 \\
\hline & Société Générale & $0.024 \%$ & $-16.23 \%$ & $23.89 \%$ & $6.16 \%$ & $2.89 \%$ & 0.43 & 7.64 \\
\hline \multirow{26}{*}{$\frac{2}{\pi}$} & Banca Carige & $0.016 \%$ & $-11.00 \%$ & $16.26 \%$ & $4.22 \%$ & $1.76 \%$ & 0.40 & 8.68 \\
\hline & Banca Finnat & $0.021 \%$ & $-11.06 \%$ & $19.33 \%$ & $5.33 \%$ & $2.05 \%$ & 1.04 & 8.01 \\
\hline & Banca Ifis & $0.011 \%$ & $-9.82 \%$ & $10.32 \%$ & $2.89 \%$ & $1.71 \%$ & 0.34 & 4.31 \\
\hline & Banca Intermobiliare & $-0.015 \%$ & $-9.97 \%$ & $16.48 \%$ & $-3.86 \%$ & $1.54 \%$ & 0.82 & 11.30 \\
\hline & Banca Monte dei Paschi & $-0.030 \%$ & $-14.40 \%$ & $14.05 \%$ & $-7.80 \%$ & $2.18 \%$ & 0.10 & 4.70 \\
\hline & Banca Pop. Emilia Romagna & $0.000 \%$ & $-9.45 \%$ & $15.59 \%$ & $0.04 \%$ & $1.68 \%$ & 0.71 & 11.32 \\
\hline & Banca Pop. Etruria & $-0.034 \%$ & $-10.33 \%$ & $11.38 \%$ & $-8.83 \%$ & $1.78 \%$ & 0.43 & 4.98 \\
\hline & Banca Pop. di Milano & $0.001 \%$ & $-13.55 \%$ & $22.32 \%$ & $0.23 \%$ & $2.48 \%$ & 0.67 & 6.92 \\
\hline & Banca Pop. di Sondrio & $0.016 \%$ & $-10.45 \%$ & $13.07 \%$ & $4.13 \%$ & $1.39 \%$ & 1.31 & 15.53 \\
\hline & Banca Profilo & $-0.022 \%$ & $-15.00 \%$ & $31.46 \%$ & $-5.75 \%$ & $2.66 \%$ & 1.81 & 18.70 \\
\hline & Banco di Desio e Brianza & $0.018 \%$ & $-11.37 \%$ & $11.88 \%$ & $4.48 \%$ & $1.77 \%$ & 0.40 & 4.54 \\
\hline & Banco di Sardegna Rsp & $0.007 \%$ & $-8.90 \%$ & $15.75 \%$ & $1.79 \%$ & $1.69 \%$ & 0.69 & 9.40 \\
\hline & Banco Popolare & $-0.016 \%$ & $-16.37 \%$ & $16.78 \%$ & $-4.17 \%$ & $2.47 \%$ & 0.20 & 6.83 \\
\hline & Cattolica Assicurazioni & $0.008 \%$ & $-9.33 \%$ & $10.92 \%$ & $1.96 \%$ & $1.65 \%$ & 0.16 & 5.33 \\
\hline & Credito Artigiano & $0.008 \%$ & $-7.17 \%$ & $20.78 \%$ & $1.96 \%$ & $1.50 \%$ & 1.59 & 19.89 \\
\hline & Credito Emiliano & $0.016 \%$ & $-14.76 \%$ & $17.25 \%$ & $4.22 \%$ & $2.31 \%$ & 0.28 & 5.09 \\
\hline & Credito Valtellinese & $-0.015 \%$ & $-10.33 \%$ & $14.72 \%$ & $-3.90 \%$ & $1.54 \%$ & 0.92 & 10.33 \\
\hline & Fondiaria Sai & $-0.024 \%$ & $-19.49 \%$ & $31.33 \%$ & $-6.27 \%$ & $2.66 \%$ & 1.00 & 16.31 \\
\hline & Generali & $-0.009 \%$ & $-8.60 \%$ & $13.10 \%$ & $-2.29 \%$ & $1.73 \%$ & 0.07 & 3.72 \\
\hline & Intesa San Paolo & $0.014 \%$ & $-16.86 \%$ & $19.68 \%$ & $3.50 \%$ & $2.63 \%$ & 0.12 & 6.35 \\
\hline & Mediobanca & $0.003 \%$ & $-10.42 \%$ & $16.57 \%$ & $0.68 \%$ & $1.88 \%$ & 0.44 & 5.93 \\
\hline & Mediolanum & $-0.003 \%$ & $-10.98 \%$ & $16.26 \%$ & $-0.64 \%$ & $2.37 \%$ & 0.43 & 3.51 \\
\hline & Milano Assicurazioni & $-0.022 \%$ & $-28.13 \%$ & $50.13 \%$ & $-5.53 \%$ & $2.56 \%$ & 2.46 & 62.39 \\
\hline & Unicredit & $-0.020 \%$ & $-17.27 \%$ & $20.93 \%$ & $-5.11 \%$ & $2.70 \%$ & 0.26 & 8.47 \\
\hline & Unipol & $-0.038 \%$ & $-14.26 \%$ & $30.33 \%$ & $-9.62 \%$ & $1.98 \%$ & 1.64 & 28.76 \\
\hline & Vittoria Assicurazioni & $0.049 \%$ & $-10.80 \%$ & $10.38 \%$ & $12.46 \%$ & $1.72 \%$ & 0.31 & 3.49 \\
\hline & Banco de Valencia & $-0.034 \%$ & $-28.38 \%$ & $40.38 \%$ & $-8.69 \%$ & $2.42 \%$ & 1.66 & 48.49 \\
\hline & Banco Pastor & $0.020 \%$ & $-9.69 \%$ & $21.05 \%$ & $5.19 \%$ & $1.67 \%$ & 1.15 & 13.51 \\
\hline & Banco Popular Espanol & $0.001 \%$ & $-9.57 \%$ & $20.68 \%$ & $0.36 \%$ & $1.97 \%$ & 0.83 & 9.19 \\
\hline & Banco Santander & $0.027 \%$ & $-11.94 \%$ & $23.22 \%$ & $7.02 \%$ & $2.30 \%$ & 0.60 & 7.76 \\
\hline & Banesto & $-0.013 \%$ & $-17.19 \%$ & $13.50 \%$ & $-3.28 \%$ & $1.68 \%$ & -0.05 & 10.75 \\
\hline & Bankinter ' $\mathrm{R}$ ' & $0.016 \%$ & $-8.43 \%$ & $14.50 \%$ & $4.12 \%$ & $2.06 \%$ & 0.70 & 4.91 \\
\hline & BBV.Argentaria & $0.011 \%$ & $-11.50 \%$ & $22.03 \%$ & $2.75 \%$ & $2.24 \%$ & 0.63 & 6.73 \\
\hline & Grupo Catalana Occidente & $0.072 \%$ & $-8.42 \%$ & $12.57 \%$ & $18.38 \%$ & $1.93 \%$ & 0.30 & 3.59 \\
\hline & Mapfre & $0.056 \%$ & $-12.58 \%$ & $17.56 \%$ & $14.46 \%$ & $2.14 \%$ & 0.55 & 6.24 \\
\hline & Sabadell & $0.008 \%$ & $-9.65 \%$ & $18.27 \%$ & $2.13 \%$ & $1.53 \%$ & 1.13 & 14.50 \\
\hline & Average & $0.008 \%$ & $-14.05 \%$ & $19.31 \%$ & $1.99 \%$ & $2.10 \%$ & 0.63 & 11.79 \\
\hline
\end{tabular}

Table 1 reports summary statistics of the daily returns for each of the 45 financial institutions in the sample over the period 17/04/2001 - 19/03/2012. Returns are calculated as percentage differences in Datastream total return index series. Average, minimum, and maximum daily returns are reported. The column 'Avg.Ann.' shows annualised average returns, calculated as $256 \times$ daily average returns. Lastly, the standard deviation, skew and kurtosis are reported. 
Table 2. Individual Financial Institution Risks.

\begin{tabular}{|c|c|c|c|c|c|c|c|}
\hline & \multirow{2}{*}{ Financial institution } & \multicolumn{5}{|c|}{ 99.90\% VaR } & \multirow{2}{*}{$\begin{array}{c}\text { Change } \\
\text { over time }\end{array}$} \\
\hline & & June 07 & June 08 & June 09 & June 10 & June 11 & \\
\hline \multirow{9}{*}{ 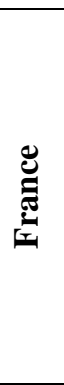 } & AXA & $13.51 \%$ & $13.40 \%$ & $14.87 \%$ & $14.31 \%$ & $13.89 \%$ & $0.39 \%$ \\
\hline & BNP Paribas & $12.95 \%$ & $11.72 \%$ & $15.81 \%$ & $14.91 \%$ & $14.37 \%$ & $1.43 \%$ \\
\hline & CIC 'A' & $4.53 \%$ & $7.49 \%$ & $8.58 \%$ & $7.80 \%$ & $7.37 \%$ & $2.84 \%$ \\
\hline & CNP Assurances & $8.21 \%$ & $7.80 \%$ & $8.91 \%$ & $8.59 \%$ & $8.19 \%$ & $-0.02 \%$ \\
\hline & April & $12.34 \%$ & $13.12 \%$ & $14.50 \%$ & $13.65 \%$ & $12.93 \%$ & $0.59 \%$ \\
\hline & Euler Hermes & $10.15 \%$ & $11.23 \%$ & $13.81 \%$ & $12.94 \%$ & $12.61 \%$ & $2.46 \%$ \\
\hline & Natixis & $6.16 \%$ & $11.29 \%$ & $21.63 \%$ & $20.90 \%$ & $21.00 \%$ & $14.85 \%$ \\
\hline & Scor SE & $21.87 \%$ & $21.03 \%$ & $19.44 \%$ & $19.30 \%$ & $18.40 \%$ & $-3.47 \%$ \\
\hline & Société Générale & $11.98 \%$ & $12.43 \%$ & $15.04 \%$ & $14.78 \%$ & $13.99 \%$ & $2.01 \%$ \\
\hline \multirow{26}{*}{$\frac{2}{\underline{\pi}}$} & Banca Carige & $5.25 \%$ & $7.03 \%$ & $11.29 \%$ & $10.92 \%$ & $9.88 \%$ & $4.63 \%$ \\
\hline & Banca Finnat & $10.02 \%$ & $9.59 \%$ & $10.13 \%$ & $10.15 \%$ & $10.06 \%$ & $0.04 \%$ \\
\hline & Banca Ifis & $9.85 \%$ & $8.94 \%$ & $9.82 \%$ & $9.54 \%$ & $9.00 \%$ & $-0.85 \%$ \\
\hline & Banca Intermobiliare & $9.78 \%$ & $8.82 \%$ & $8.44 \%$ & $8.12 \%$ & $7.94 \%$ & $-1.84 \%$ \\
\hline & Banca Monte dei Paschi & $8.77 \%$ & $8.95 \%$ & $9.29 \%$ & $9.26 \%$ & $8.91 \%$ & $0.14 \%$ \\
\hline & Banca Pop. Emilia Romagna & $7.38 \%$ & $6.46 \%$ & $9.39 \%$ & $9.22 \%$ & $9.18 \%$ & $1.80 \%$ \\
\hline & Banca Pop. Etruria & $4.87 \%$ & $5.93 \%$ & $7.12 \%$ & $7.67 \%$ & $7.31 \%$ & $2.43 \%$ \\
\hline & Banca Pop. di Milano & $7.74 \%$ & $8.03 \%$ & $11.67 \%$ & $10.96 \%$ & $10.89 \%$ & $3.15 \%$ \\
\hline & Banca Pop. di Sondrio & $5.95 \%$ & $7.68 \%$ & $7.76 \%$ & $7.52 \%$ & $7.15 \%$ & $1.19 \%$ \\
\hline & Banca Profilo & $12.11 \%$ & $10.93 \%$ & $16.31 \%$ & $14.14 \%$ & $14.28 \%$ & $2.17 \%$ \\
\hline & Banco di Desio e Brianza & $7.35 \%$ & $8.05 \%$ & $8.53 \%$ & $8.22 \%$ & $8.07 \%$ & $0.72 \%$ \\
\hline & Banco di Sardegna Rsp & $7.62 \%$ & $7.77 \%$ & $8.59 \%$ & $8.52 \%$ & $8.10 \%$ & $0.48 \%$ \\
\hline & Banco Popolare & $8.16 \%$ & $7.47 \%$ & $16.83 \%$ & $14.70 \%$ & $14.09 \%$ & $5.92 \%$ \\
\hline & Cattolica Assicurazioni & $7.81 \%$ & $7.95 \%$ & $9.55 \%$ & $9.00 \%$ & $8.87 \%$ & $1.05 \%$ \\
\hline & Credito Artigiano & $4.21 \%$ & $5.08 \%$ & $7.51 \%$ & $7.54 \%$ & $7.22 \%$ & $3.01 \%$ \\
\hline & Credito Emiliano & $10.06 \%$ & $9.97 \%$ & $13.24 \%$ & $12.43 \%$ & $12.03 \%$ & $1.97 \%$ \\
\hline & Credito Valtellinese & $5.61 \%$ & $5.05 \%$ & $8.47 \%$ & $8.83 \%$ & $8.31 \%$ & $2.70 \%$ \\
\hline & Fondiaria Sai & $12.41 \%$ & $11.17 \%$ & $13.15 \%$ & $11.25 \%$ & $10.82 \%$ & $-1.59 \%$ \\
\hline & Generali & $10.21 \%$ & $10.23 \%$ & $9.28 \%$ & $8.51 \%$ & $8.65 \%$ & $-1.56 \%$ \\
\hline & Intesa San Paolo & $10.14 \%$ & $10.43 \%$ & $15.97 \%$ & $15.16 \%$ & $14.22 \%$ & $4.07 \%$ \\
\hline & Mediobanca & $9.03 \%$ & $8.67 \%$ & $9.05 \%$ & $9.12 \%$ & $8.81 \%$ & $-0.22 \%$ \\
\hline & Mediolanum & $9.83 \%$ & $9.38 \%$ & $10.47 \%$ & $9.99 \%$ & $9.80 \%$ & $-0.03 \%$ \\
\hline & Milano Assicurazioni & $7.59 \%$ & $7.35 \%$ & $11.08 \%$ & $10.01 \%$ & $10.67 \%$ & $3.08 \%$ \\
\hline & Unicredit & $8.62 \%$ & $8.09 \%$ & $18.98 \%$ & $15.08 \%$ & $14.49 \%$ & $5.87 \%$ \\
\hline & Unipol & $5.03 \%$ & $6.10 \%$ & $11.83 \%$ & $10.25 \%$ & $10.16 \%$ & $5.13 \%$ \\
\hline & Vittoria Assicurazioni & $7.85 \%$ & $7.55 \%$ & $8.87 \%$ & $8.40 \%$ & $8.17 \%$ & $0.32 \%$ \\
\hline \multirow{10}{*}{$\begin{array}{l}\text { 芯 } \\
\text { के }\end{array}$} & Banco de Valencia & $6.61 \%$ & $6.02 \%$ & $8.70 \%$ & $9.21 \%$ & $9.20 \%$ & $2.59 \%$ \\
\hline & Banco Pastor & $7.99 \%$ & $8.37 \%$ & $8.69 \%$ & $8.12 \%$ & $7.78 \%$ & $-0.21 \%$ \\
\hline & Banco Popular Espanol & $7.36 \%$ & $7.15 \%$ & $9.54 \%$ & $9.32 \%$ & $9.32 \%$ & $1.97 \%$ \\
\hline & Banco Santander & $9.80 \%$ & $9.93 \%$ & $11.86 \%$ & $12.18 \%$ & $11.80 \%$ & $2.00 \%$ \\
\hline & Banesto & $12.11 \%$ & $10.46 \%$ & $11.00 \%$ & $10.54 \%$ & $10.04 \%$ & $-2.07 \%$ \\
\hline & Bankinter ' $\mathrm{R}$ ' & $6.82 \%$ & $7.85 \%$ & $9.06 \%$ & $8.49 \%$ & $8.55 \%$ & $1.73 \%$ \\
\hline & BBV.Argentaria & $9.67 \%$ & $9.57 \%$ & $11.26 \%$ & $10.81 \%$ & $10.98 \%$ & $1.30 \%$ \\
\hline & Grupo Catalana Occidente & $5.80 \%$ & $6.61 \%$ & $9.13 \%$ & $9.18 \%$ & $9.09 \%$ & $3.28 \%$ \\
\hline & Mapfre & $7.43 \%$ & $6.90 \%$ & $11.27 \%$ & $10.78 \%$ & $10.23 \%$ & $2.79 \%$ \\
\hline & Sabadell & $6.71 \%$ & $6.70 \%$ & $8.02 \%$ & $8.09 \%$ & $7.74 \%$ & $1.03 \%$ \\
\hline & Average & $8.78 \%$ & $8.93 \%$ & $11.42 \%$ & $10.85 \%$ & $10.55 \%$ & $1.76 \%$ \\
\hline
\end{tabular}

Table 2 reports, for each of the 45 financial institutions in the sample, estimates of the $99.90 \% \mathrm{VaR}-$ levels. The starting date of the sample is 17 April 2001. The VaR is calculated for the middle trading day of each calendar month that is reported under the column headings of the top row, i.e., 15 June 2007, 16 June 2008, 15 June 2009, 15 June 2010, and 16 June 2011. The last column reports the change in VaR 
between 15 June 2007 and 16 June 2011. VaR is estimated in the following way: $\operatorname{VaR}=x_{k+1}\left(\frac{k}{M p}\right)^{\hat{\gamma}}$ in which $\hat{\gamma}=\frac{1}{k} \sum_{j=1}^{k} \ln \left(\frac{x_{j}}{x_{k+1}}\right)$

where $\hat{\gamma}$ is the tail shape estimator and $x_{j}$ is the $j^{\text {th }}$ order statistic, i.e., $x_{j} \geq x_{j-1}$ for $j=2, . ., M$, in which $M$ equals the number of observations. For the periods to 15 June 2007, 16 June 2008, 15 June 2009, 15 June 2010 and 16 June 2011, the number of observations $M$ equals 1,612, 1,873, 2,133, 2,394, and 2,655, respectively. The number of order statistics used in the estimation $k$ depends on the length of the period analysed. For the periods to 15 June 2007, 16 June 2008, 15 June 2009, 15 June 2010 and 16 June 2011, the number of order statistics $k$ is set equal to $40,43,46,49$ and 52, respectively. The exceedance probability (or significance level) $p$ is set equal to $0.1 \%$.

Table 3. Systemic Financial Institution Risks.

\begin{tabular}{|c|c|c|c|c|c|c|c|}
\hline & \multirow{2}{*}{ Financial institution } & \multicolumn{5}{|c|}{ Systemic Risk } & \multirow{2}{*}{$\begin{array}{c}\text { Change } \\
\text { over time }\end{array}$} \\
\hline & & June 07 & June 08 & June 09 & June 10 & June 11 & \\
\hline \multirow{9}{*}{ 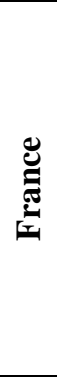 } & AXA & $30.00 \%$ & $27.91 \%$ & $27.45 \%$ & $27.30 \%$ & $27.40 \%$ & $-2.60 \%$ \\
\hline & BNP Paribas & $31.25 \%$ & $29.36 \%$ & $28.26 \%$ & $28.06 \%$ & $28.37 \%$ & $-2.88 \%$ \\
\hline & $\mathrm{CIC}^{\prime} \mathrm{A}^{\prime}$ & $6.25 \%$ & $12.21 \%$ & $15.49 \%$ & $15.05 \%$ & $14.90 \%$ & $8.65 \%$ \\
\hline & CNP Assurances & $17.50 \%$ & $19.77 \%$ & $19.29 \%$ & $17.86 \%$ & $18.03 \%$ & $0.53 \%$ \\
\hline & April & $15.63 \%$ & $14.24 \%$ & $13.59 \%$ & $13.27 \%$ & $13.46 \%$ & $-2.16 \%$ \\
\hline & Euler Hermes & $24.06 \%$ & $22.38 \%$ & $23.37 \%$ & $22.45 \%$ & $22.60 \%$ & $-1.47 \%$ \\
\hline & Natixis & $19.69 \%$ & $16.28 \%$ & $21.20 \%$ & $19.39 \%$ & $19.95 \%$ & $0.26 \%$ \\
\hline & Scor SE & $21.25 \%$ & $18.60 \%$ & $15.49 \%$ & $15.56 \%$ & $14.90 \%$ & $-6.35 \%$ \\
\hline & Société Générale & $30.00 \%$ & $30.52 \%$ & $30.43 \%$ & $29.34 \%$ & $29.81 \%$ & $-0.19 \%$ \\
\hline \multirow{25}{*}{ 롵 } & Banca Carige & $8.80 \%$ & $9.58 \%$ & $19.48 \%$ & $21.80 \%$ & $21.46 \%$ & $12.66 \%$ \\
\hline & Banca Finnat & $10.60 \%$ & $10.23 \%$ & $17.39 \%$ & $16.16 \%$ & $15.31 \%$ & $4.71 \%$ \\
\hline & Banca Ifis & $7.60 \%$ & $8.00 \%$ & $10.70 \%$ & $9.47 \%$ & $9.23 \%$ & $1.63 \%$ \\
\hline & Banca Intermobiliare & $15.80 \%$ & $16.00 \%$ & $20.17 \%$ & $18.45 \%$ & $17.23 \%$ & $1.43 \%$ \\
\hline & Banca Monte dei Paschi & $17.60 \%$ & $17.77 \%$ & $21.91 \%$ & $24.24 \%$ & $24.23 \%$ & $6.63 \%$ \\
\hline & Banca Pop. Emilia Romagna & $10.50 \%$ & $11.81 \%$ & $21.04 \%$ & $22.29 \%$ & $22.00 \%$ & $11.50 \%$ \\
\hline & Banca Pop. Etruria & $14.30 \%$ & $16.47 \%$ & $22.96 \%$ & $25.06 \%$ & $23.92 \%$ & $9.62 \%$ \\
\hline & Banca Pop. di Milano & $16.90 \%$ & $17.58 \%$ & $27.48 \%$ & $30.61 \%$ & $29.62 \%$ & $12.72 \%$ \\
\hline & Banca Pop. di Sondrio & $7.00 \%$ & $7.91 \%$ & $23.22 \%$ & $25.39 \%$ & $24.46 \%$ & $17.46 \%$ \\
\hline & Banca Profilo & $18.20 \%$ & $16.84 \%$ & $24.09 \%$ & $22.45 \%$ & $20.46 \%$ & $2.26 \%$ \\
\hline & Banco di Desio e Brianza & $13.80 \%$ & $14.05 \%$ & $16.61 \%$ & $16.24 \%$ & $16.46 \%$ & $2.66 \%$ \\
\hline & Banco di Sardegna Rsp & $16.20 \%$ & $18.33 \%$ & $23.91 \%$ & $23.84 \%$ & $22.69 \%$ & $6.49 \%$ \\
\hline & Banco Popolare & $14.90 \%$ & $13.40 \%$ & $28.52 \%$ & $28.49 \%$ & $27.62 \%$ & $12.72 \%$ \\
\hline & Cattolica Assicurazioni & $17.50 \%$ & $18.23 \%$ & $25.04 \%$ & $23.76 \%$ & $23.38 \%$ & $5.88 \%$ \\
\hline & Credito Artigiano & $12.50 \%$ & $12.19 \%$ & $20.26 \%$ & $16.98 \%$ & $18.00 \%$ & $5.50 \%$ \\
\hline & Credito Emiliano & $19.90 \%$ & $16.37 \%$ & $26.52 \%$ & $25.55 \%$ & $25.23 \%$ & $5.33 \%$ \\
\hline & Credito Valtellinese & $11.40 \%$ & $12.93 \%$ & $25.39 \%$ & $26.61 \%$ & $25.85 \%$ & $14.45 \%$ \\
\hline & Fondiaria Sai & $14.00 \%$ & $12.00 \%$ & $18.78 \%$ & $20.49 \%$ & $20.23 \%$ & $6.23 \%$ \\
\hline & Generali & $22.70 \%$ & $20.65 \%$ & $25.22 \%$ & $27.92 \%$ & $27.23 \%$ & $4.53 \%$ \\
\hline & Intesa San Paolo & $19.40 \%$ & $18.14 \%$ & $27.74 \%$ & $29.80 \%$ & $29.15 \%$ & $9.75 \%$ \\
\hline & Mediobanca & $20.50 \%$ & $20.65 \%$ & $25.57 \%$ & $27.18 \%$ & $27.00 \%$ & $6.50 \%$ \\
\hline & Mediolanum & $22.00 \%$ & $20.47 \%$ & $21.57 \%$ & $22.53 \%$ & $21.38 \%$ & $-0.62 \%$ \\
\hline & Milano Assicurazioni & $17.20 \%$ & $17.58 \%$ & $26.70 \%$ & $28.33 \%$ & $24.62 \%$ & $7.42 \%$ \\
\hline & Unicredit & $19.60 \%$ & $17.58 \%$ & $31.04 \%$ & $32.65 \%$ & $31.85 \%$ & $12.25 \%$ \\
\hline & Unipol & $10.80 \%$ & $14.23 \%$ & $29.22 \%$ & $31.35 \%$ & $28.77 \%$ & $17.97 \%$ \\
\hline
\end{tabular}




\begin{tabular}{|l|l|c|c|c|c|c|c|}
\hline & Vittoria Assicurazioni & $10.30 \%$ & $9.67 \%$ & $18.78 \%$ & $19.02 \%$ & $18.62 \%$ & $8.32 \%$ \\
\hline \multirow{4}{*}{ Banco de Valencia } & $16.11 \%$ & $23.00 \%$ & $29.95 \%$ & $35.37 \%$ & $31.84 \%$ & $15.73 \%$ \\
\cline { 2 - 7 } & Banco Pastor & $14.44 \%$ & $19.38 \%$ & $19.08 \%$ & $20.63 \%$ & $18.80 \%$ & $4.36 \%$ \\
\cline { 2 - 7 } & Banco Popular Espanol & $15.83 \%$ & $22.22 \%$ & $37.20 \%$ & $35.83 \%$ & $35.04 \%$ & $19.21 \%$ \\
\cline { 2 - 7 } & Banco Santander & $18.61 \%$ & $19.64 \%$ & $34.06 \%$ & $38.55 \%$ & $38.68 \%$ & $20.06 \%$ \\
\cline { 2 - 7 } & Banesto & $16.94 \%$ & $26.10 \%$ & $33.09 \%$ & $36.51 \%$ & $36.54 \%$ & $19.59 \%$ \\
\cline { 2 - 7 } & Bankinter 'R' & $22.50 \%$ & $28.68 \%$ & $33.57 \%$ & $36.73 \%$ & $35.90 \%$ & $13.40 \%$ \\
\cline { 2 - 7 } & BBV.Argentaria & $17.22 \%$ & $18.35 \%$ & $34.30 \%$ & $39.00 \%$ & $38.68 \%$ & $21.45 \%$ \\
\cline { 2 - 7 } & Grupo Catalana Occidente & $13.33 \%$ & $17.31 \%$ & $21.98 \%$ & $23.13 \%$ & $23.29 \%$ & $9.96 \%$ \\
\cline { 2 - 7 } & Mapfre & $14.17 \%$ & $21.71 \%$ & $32.37 \%$ & $36.51 \%$ & $36.32 \%$ & $22.16 \%$ \\
\cline { 2 - 7 } & Sabadell & $18.06 \%$ & $25.32 \%$ & $29.71 \%$ & $32.88 \%$ & $30.13 \%$ & $12.07 \%$ \\
\hline \multicolumn{2}{|r|}{ Average } & $16.43 \%$ & $17.58 \%$ & $24.36 \%$ & $25.29 \%$ & $24.62 \%$ & $8.19 \%$ \\
\hline
\end{tabular}

Table 3 documents, for each of the 45 financial institutions in the sample, estimates of the systemic risk levels. The starting date is 17 April 2001. For each financial institution, conditional-co-crash (CCC) probability estimates are averaged across all financial institutions that are listed on the same exchange. The CCC probability estimates are calculated for the middle trading day of the calendar month, as

follows: $C C C=2-\frac{1}{k} \sum_{t=1}^{M} I\left\{\left(v_{i t}>x_{i, M-k}\right) \cup\left(v_{m t}>x_{m, M-k}\right)\right\}$

where $v_{i t}$ denotes the percentage return of stock $i$ at time t, with $i=1, . ., S$ and $t=1, . ., M$, in which $S$ equals the number of stocks and $M$ equals the number of observations. For the periods to 15 June 2007, 16 June 2008, 15 June 2009, 15 June 2010 and 16 June 2011, the number of observations $M$ equals 1,612; $1,873,2,133,2,394$, and 2,655, respectively. The number of order statistics used in the estimation $k$ depends on the length of the period analysed. For the periods to 15 June 2007, 16 June 2008, 15 June 2009, 15 June 2010 and 16 June 2011, the number of order statistics $k$ is set equal to 40, 43, 46, 49 and 52 , respectively. The exceedance probability (or significance level) $p$ is set equal to $0.1 \%$. The last column measures how the financial institutions' systemic risk levels changed between June 2007 and June 2011. 


\section{Appendix I. Extreme Value Theory}

Below, we briefly describe the main elements of EVT used in this study. We refer to Pais and Stork (2011) for further details. The Hill (1975) estimator of a return distribution's tail fatness is used. The stock return distribution is assumed to follow the Power Law, and thus, the probability that return $v$ exceeds quantile $q$, in the tail of the distribution, equals:

$$
p=\operatorname{Pr}[v>q]=c q^{-\alpha}
$$

Parameter $c$ in equation (1) is a positive constant. Furthermore, the so-called tail index parameter

$$
\alpha \text { is estimated by computing: } \hat{\gamma}=\frac{1}{k} \sum_{j=1}^{k} \ln \left(\frac{x_{j}}{x_{k+1}}\right)
$$

Because it holds that $\hat{\alpha}=1 / \hat{\gamma}$, once the shape parameter $\gamma$ is estimated, the value of parameter $\hat{\alpha}$ follows automatically. Parameter $k$ equals the number of extreme returns used in the estimation. Furthermore, in equation (2), $x_{j}$ is the $j^{\text {th }}$ order statistic, i.e., $x_{j} \geq x_{j-1}$ for $j=2, . ., M$, in which $M$ equals the number of observations. Next, we use the quantile estimator from De Haan et al. (1994) and Straetmans et al. (2008):

$\operatorname{VaR}=x_{k+1}\left(\frac{k}{M p}\right)^{\hat{\gamma}}$

Parameter $p$ in equation (3) measures the likelihood of exceeding some negative return threshold, which in this study equals a very low level of $0.1 \%$. Consequently, we estimate $99.9 \%$ VaR levels. We use multivariate EVT to estimate the conditional-co-crash (CCC) probability of two stock prices exhibiting extremely negative returns at the same time. We set crash return levels such that $\operatorname{Pr}\left[v_{i t}>q_{i}\right]=p$ for all $i=1, \ldots, S$. Variable $v_{i t}$ measures the return of stock $i$ at time $t$, with $t=1, . ., M$. The likelihood that institution $i$ crashes given that institution $m$ also crashes equals: $C C C \equiv \operatorname{Pr}\left[v_{i t}>q_{i} \mid v_{m t}>q_{m}\right]$

A non-parametric estimator of the CCC-probability is used:

$$
C C C=2-\frac{1}{k} \sum_{t=1}^{M} I\left\{\left(v_{i t}>x_{i, M-k}\right) \cup\left(v_{m t}>x_{m, M-k}\right)\right\}
$$

In equation (5), $I$ refers to the indicator function, and variables $x_{i, M-k}$ and $x_{m, M-k}$ are the $k^{\text {th }}$ the highest order statistics of stocks $i$ and $m$, respectively. 